\author{
Monique R. Bernsen \\ Amber D. Moelker \\ Piotr A. Wielopolski \\ Sandra T. van Tiel \\ Gabriel P. Krestin
}

\section{Labelling of mammalian cells for visualisation by MRI}

Received: 15 January 2009

Revised: 11 June 2009

Accepted: 23 June 2009

Published online: 12 August 2009

(C) The Author(s) 2009.

This article is published with open access at Springerlink.com

M. R. Bernsen · A. D. Moelker .

P. A. Wielopolski - S. T. van Tiel ·

G. P. Krestin

Department of Radiology,

Erasmus MC-University Medical

Center Rotterdam,

Dr. Molewaterplein 50,

3015 GE Rotterdam, The Netherlands

\author{
M. R. Bernsen $(\square)$ \\ Department of Radiology, \\ Erasmus MC, \\ P.O. Box 2040, 3000 CA \\ Rotterdam, The Netherlands \\ e-mail: m.bernsen@erasmusmc.nl \\ Tel.: +31-10-7035987 \\ Fax: +31-10-7034033
}

\begin{abstract}
Through labelling of cells with magnetic contrast agents it is possible to follow the fate of transplanted cells in vivo with magnetic resonance imaging (MRI) as has been demonstrated in animal studies as well as in a clinical setting. A large variety of labelling strategies are available that allow for prolonged and sensitive
\end{abstract}

detection of the labelled cells with MRI. The various protocols each harbour specific advantages and disadvantages. In choosing a particular labelling strategy it is also important to ascertain that the labelling procedure does not negatively influence cell functionality, for which a large variety of assays are available. In order to overcome the challenges still faced in fully exploiting the benefits of in vivo cell tracking by MRI a good understanding and standardisation of the procedures and assays used will be crucial.

Keywords Cell labelling · Contrast agents - Cell tracking - Apoptosis · MRI

\section{Introduction}

Labelling of cells with magnetic contrast agents has been the subject of research in a considerable number of studies. Because of the increased use of cells as therapeutic agents or vehicles, the need for noninvasive imaging of cells in vivo has developed. For studies regarding the development of cell-based therapeutic strategies, and for monitoring the efficacy and safety of such therapies, it is essential for the fate of transplanted cells to be monitored in vivo.

Various methods are available for in vivo cell imaging, including optical imaging techniques [1] and nuclear imaging techniques such as positron emission tomography (PET) [2], single-photon emission tomography (SPECT) [3] and MRI [4]. Each of these techniques has its own advantages and limitations. In vivo cell imaging by optical techniques has the advantage that it is a high-throughput method with high sensitivity and multispectral capabilities. Optical imaging techniques, however, are limited by their poor spatial resolution and penetration depth making them mostly applicable in small laboratory animals or for superficial locations, and as yet they are not suitable for clinical translation. PET and SPECT offer high sensitivity for detection, and quantifiable results. However the spatial resolution of these techniques is low; the half-life of the tracers is short and there are safety issues involved with ionising radiation, limiting their use in longitudinal studies. MRI offers several advantages for in vivo cell tracking: it is an intrinsic noninvasive technique, it does not involve the use of ionising radiation, it has high spatial and temporal resolution capabilities, it provides information in an anatomical context and it offers the possibility to assess functional aspects of tissues. Because of these advantages MRI has been promoted as a promising technique for in vivo cell tracking. A prerequisite for imaging of cells by MRI is the association of contrast agents with the cells of interest. The contrast agent must alter the MR signal parameters to allow detection. 
Various groups have demonstrated that cells can be labelled with paramagnetic particles allowing visualisation by MRI, even at the single cell level [5-11]. To label cells, contrast agents should be bound to the external cell membrane or internalised into the cytosol or intracellular vesicles. A variety of approaches, in terms of labelling method and type of contrast agent used, have been described for the effective labelling of cells with contrast agents [12-24]. For safe clinical application of labelled cells both short- and long-term toxicity studies are needed. However, before contrast agents can be administered to patients, potential adverse effects in vivo following their metabolism should be investigated as well. Imaging labelled cells with contrast agents can provide an exquisite approach to following the fate of the injected cells.

This article provides an overview of these different approaches used for cell labelling and their specific benefits and limitations. Furthermore, several methods to assess labelling efficiency will be compared and several assays to assess the toxicity of the contrast agents used for cell labelling and their effect on cell function will be discussed. Finally, a brief overview of image acquisition possibilities and limitations will be presented.

\section{Applications of paramagnetic cell labelling}

The fact that cells can be visualised by MRI, when labelled with paramagnetic nanoparticles, has created the possibility to assess the fate of transplanted cells in vivo. Various applications for in vivo cell imaging by MRI have been reported and proposed. The various applications include studies regarding the fate of transplanted stem cells in neurological disorders [25], cardiovascular disease [4] and joint disease [26], survival of transplanted pancreatic islets [27] and homing and function of immune effector cells in cell-mediated treatment of cancer [28]. For additional information on applications of cell imaging by MRI we refer the reader to some excellent recent reviews and a recently published book on cellular and molecular imaging by MRI [25, 29-35].

In vivo cell imaging by MRI has also already entered the clinical arena. The first report describing the use of MRI to monitor the fate of transplanted cells was by De Vries et al. [15]. In this paper, autologous dendritic cells loaded with tumour-derived antigenic peptides were labelled with superparamagnetic iron oxide particles (SPIO) before injection in melanoma patients. The study showed that MRI allowed for the assessment of the accuracy of dendritic cell delivery and of the inter- and intranodal cell migration patterns of the injected dendritic cells over the following days. Thereafter, Zhu et al. [36] reported on a feasibility study performed in two patients, of tracking neural stem cells labelled with SPIO in patients with brain trauma. They showed that the migration of the stem cells could be monitored by MRI. More recently, Toso et al. [37] reported on MRI-based monitoring of pancreatic islet grafts labelled with SPIO in patients with type 1 diabetes. While some technical limitations in terms of visualisation of the grafts were encountered, the use of SPIO-labelled cells did not affect the in vitro or in vivo functionality of the grafts.

\section{Contrast agents for cell labelling}

To date, many different contrast agents have been used for cellular MR imaging [5, 20, 37-47]. MR contrast agents can broadly be divided into paramagnetic agents, the socalled T1 agents (gadolinium, manganese etc.), and superparamagnetic agents, the T2 agents (e.g. iron oxide nanoparticles) [48].

\section{Iron oxide particles}

The effect of iron particles on the contrast between labelled and unlabelled cells is stronger than that of other paramagnetic agents. Usually, iron oxide particles require stabilisation by a surface coating of dextran to prevent aggregation. Dextran-coated iron oxide nanoparticles are biodegradable and biocompatible. There are big differences between the sizes of the various magnetic nanoparticles [20]. For example, Feridex I.V. ${ }^{\circledR}$ (Advanced Magnetic Industries, Cambridge, Maryland, USA), which is a ferumoxide, has particles that range from 120 to $180 \mathrm{~nm}$ in size; Sinerem ${ }^{\circledR}$ (Guerbet, Villepinte, France), which consists of ferumoxtran-10, has particles that range from 15 to $30 \mathrm{~nm}$ in size; Resovist ${ }^{\circledR}$ (Bayer Schering Pharma, Berlin, Germany), which is a ferucarbotran, consists of particles that are $60 \mathrm{~nm}$ in size. Iron oxide particles can be classified into superparamagnetic iron oxide particles (SPIO), such as Feridex ${ }^{\circledR}$ and Endorem ${ }^{\circledR}$ (Guerbet, Gorinchem, the Netherlands) [35, 49-53]; ultrasmall superparamagnetic iron oxide particles (USPIO), such as Combidex ${ }^{\circledR}$ (Advanced Magnetic Industries, Cambridge, Maryland, USA) and Sinerem ${ }^{\circledR}$ ) [54-57]; very small superparamagnetic iron oxide particles (VSOP) [58-60]; ferrofluids $[61,62]$; monocrystalline iron oxide nanoparticles (MION) $[45,63]$; micrometre-sized iron oxide particles (MPIO) $[16,19]$; and cross-linked iron oxide particles (CLIO) [64-66].

All these different particles have their specific characteristics [67-69]. Variations in size, surface charge, coating properties etc. influence the pharmacokinetics, biodistribution, uptake efficiency, metabolism and biocompatibility of the particles. For example, the smaller dextran-coated USPIO have a longer blood half-life than SPIO. SPIO are clinically used for liver imaging; Kupffer cells (liver macrophages) efficiently and quickly take up SPIO as opposed to tumour cells, thus facilitating detection and staging of liver tumours. USPIO are mostly used in clinical 
trials for metastatic lymph node imaging, for imaging inflammatory tissue and as a blood pool agent. Furthermore, SPIO have a higher magnetic susceptibility and T2 relaxivity. Although SPIO are easily internalised by macrophages, uptake by nonphagocytic cells or slowly dividing cells is low. Therefore, high, potentially toxic concentrations are needed for efficient cell labelling of nonphagocytic cells. When labelling cells with paramagnetic particles, it is essential to determine the toxic effects of the contrast agent or the labelling procedure on the cells. Adverse effects in terms of cell viability, proliferation capacity, differentiation capacity and cell function need to be avoided. The lack of significant adverse effects of labelling of cells with iron oxide particles has been reported in a large number of studies; however, some adverse effects or changes in behaviour of the labelled cells have been reported: these include reduced differentiation capabilities of labelled mesenchymal stem cells [70], altered expression of proteins [71] and changed in vivo behaviour [53]. Although only few studies exist that report on potential adverse effects of paramagnetic labelling on cells, further studies on potential adverse effects of labelled cells in vivo need to be performed.

The particles consist of an iron oxide core and are usually coated with dextran or siloxanes [68] encapsulated by a polymer [16], or modified in other ways to enhance internalisation by cells and to prevent aggregation. The coating on the outer surface allows further biochemical manipulation. For example, dextran-coated iron oxide particles can be chemically conjugated to proteins such as monoclonal antibodies [72]. In general, monoclonal antibody-guided magnetic particles can provide a stronger contrast enhancement of specific target cells than particles without antibody guidance.

It is beneficial if two different imaging techniques can visualise the same contrast agent particle. For example, from the bacteria Magnetospirillum gryphiswaldense magnetic nanoparticles can be harvested and coupled covalently to a fluorescence dye [73]. These fluorochromecoupled magnetosomes can be imaged using MRI as well as optical imaging methods. The use of this bimodal contrast agent benefits from the high spatial resolution of the MRI and the high sensitivity of fluorescence imaging. However, the possibility of using these magnetosomes in vivo needs to be investigated, especially since the protein shell of these magnetosomes may gave rise to immunological reactions. Two imaging techniques can also be combined using other particles [73-76].

\section{Gadolinium compounds}

Gadolinium compounds can also be used for cellular labelling. In general, they induce a predominant $\mathrm{T} 1$ shortening and thus high signal on T1-weighted MR images, which is favoured whenever the surrounding tissue has low signal intensity. However, detection of Gd compounds by MRI is much less sensitive than for SPIO $[40,77]$ and the contrast behaviour or relaxivity of $\mathrm{Gd}$ chelates may depend on the cell compartment in which these $\mathrm{Gd}$ compounds end up in. The cellular localisation of Gd-based probes depends on the size of the contrast agent used and/or the labelling method [77].

Internalisation of gadolinium can be accomplished by exposure of cells to $\mathrm{Gd}$ chelates [78, 79] or by using liposomes [23]. Liposomes are double-layered lipid spheres that can incorporate gadolinium inside the water or lipid phase. Gadolinium nanoparticles coupled to a fluorophore can also be used for cellular labelling [23]. These particles are constructed from lipid monomers with diacetylene bonds that are sonicated and photolysed to form polymerised nanoparticles. These nanoparticles allow efficient cell labelling. Another application of gadolinium is the conjugation of ionic gadolinium $\left(\mathrm{Gd}^{3+}\right)$ chelates to proteins that bind to dying cells [80]. This enables targeted MRI detection of cell death (apoptosis) in tumours after treatment with a chemotherapeutic agent. It is currently not clear how long gadolinium-labelled cells can be tracked in vivo and if there are any toxic side effects.

\section{New developments for contrast manipulation}

A new approach to cell tracking for MRI has recently been developed, in which genes encoding expression of proteins involved in iron metabolism, e.g. ferritin and transferrin receptors, are used as cellular MR reporter genes [81-84]. In this approach a gene, encoding the protein of choice, is introduced into the cell using molecular techniques [31]. These molecular techniques can be employed such that the newly introduced gene continuously (over)expresses the protein [85], or such that the protein is expressed simultaneously with another specific gene of choice, e.g. the endothelial cell adhesion molecule VE-cadherin [81], or that the protein is only expressed after induction of expression [81]. The (over)expression of proteins involved in iron metabolism then result in accumulation of iron in the cell leading to altered signals on MRI.

There are some potential pitfalls of using MR reporter genes to monitor transgene expression such as the low sensitivity of detection as well as difficult and sometimes delayed interpretation of signal changes, meaning that it may take some time before accumulated iron has reached detectable levels. However, MR reporter genes have the potential to provide information on the biodistribution and viability of cells after injection. A further major advantage of using MRI reporter genes over labelling of cells with paramagnetic particles is that when cells divide, the newly introduced gene is propagated in the daughter cells, and will give similar signal effects as the parent cell. For exogenously introduced particles, the particle content per cell will become diluted through subsequent cell divisions 
with ultimate loss of signal $[86,87]$. Further development of more sensitive and selective reporters, combined with improvements in detection sequences, will also help in the understanding of intracellular biological processes and the molecular bases of diseases.

Other novel contrast agents have also recently been explored for use in cell imaging. These include labelling of cells with manganese-based contrast agents, fluorine-based contrast agents [88-90] and chemical exchange saturation transfer (CEST) agents [91-93].

For manganese-based contrast agents proposed advantages include signal enhancement on MR images, instead of signal loss as seen with iron oxide particles, and the fact that cells can be efficiently labelled without the need for additional compounds. Disadvantages on the other hand may arise from toxic effects of manganese, low MRI sensitivity for detection and rapid clearance of manganese from cells [86, 87]. For fluorine-based cell imaging the main proposed advantages are the highly specific imaging of labelled cells, since there is no native background signal as seen with proton imaging used with regular T1- or T2type contrast agents, and that quantification of the contrast agent and thus indirectly the number of cells is more straightforward than with iron oxide particles [89]. Limited sensitivity for MRI detection may, however, also be a disadvantage for fluorine-based cell imaging. CEST agents function by reducing the water proton signal through a chemical exchange site on the agent via saturation transfer $[91,92]$. MR signal arising from protons tightly bound to a specific class of molecules (proteins, lipids etc.) could be selectively presaturated, and this saturation could then be transferred to the signal of the bulk water, producing a decrease in bulk water signal intensity. Major advantages of CEST agents arise from the fact that the contrast effect only arises after the saturation pulse is administered at the specific frequency. Therefore, the contrast can be switched on and off and multispectral imaging can be performed, meaning that various cell populations labelled with different contrast agents can be visualised [94]. Furthermore, CEST agents can be used to monitor clinically relevant physiological properties such as in vivo temperature mapping [94], $\mathrm{pH}$ mapping [95] and monitoring of enzyme activity [96]. Furthermore, the combination with liposomes offers the possibility of liposome-based chemical exchange saturation transfer (lipoCEST) [97]. The size of liposomes can be exploited to enhance the lipoCEST contrast. The size of the liposome determines the amount of water protons available in the liposomal vesicle and the exchange rate of water molecules over the liposomal membrane $[98,99]$. Through these effects, smaller liposomes are more efficient in saturation transfer but larger liposomes perform better on a lipid molar-based comparison.

Another technical development for monitoring cell biological and physiological processes with high clinical potential is ${ }^{13} \mathrm{C}$ labelling of molecules [97]. Depending on the molecules selected, MR imaging or spectroscopy can be used for in vivo monitoring of metabolic processes $[100,101]$, mapping of tissue perfusion [102] and $\mathrm{pH}$ mapping of tissue spaces [103].

\section{Cell labelling methods}

Association of cells with contrast agents can be achieved by nonspecific as well as specific cell labelling approaches (see below). For each of these approaches several biological or biochemical principles can be employed. In most cases, however, a rather complex biological process called endocytosis, which encompasses a variety of pathways, is central to the uptake of material from the extracellular environment into the cell [103-107]. Depending on the cell type, the contrast agent used and the specific cell labelling method used, contrast agents can be incorporated into the cell by phagocytosis, pinocytosis, receptor-mediated endocytosis, and caveolin-dependent and -independent endocytosis. In general, cell labelling methods are aimed at incorporation of the label into the cell (Fig. 1a-c). Various strategies are possible and are either mainly suitable for ex vivo labelling of cells or can be used for both in vitro and in vivo labelling strategies.

\section{Nonspecific cell labelling}

Nonspecific cell labelling approaches can in principle be used for all kinds of cells as they are based on general biological or biochemical principles. Because of the lack of specificity of these approaches, nonspecific cell labelling is generally suitable for ex vivo cell labelling, but can also be used in vivo. Nonspecific cell labelling can be performed on mixed, undefined as well as on defined and purified cell populations depending on the labelling method used. The efficacy by which this can be done strongly depends on the cell type [63], the specific labelling method [108] (see below) and the type of contrast agent used [14, 56, 109].

Nonspecific cell labelling approaches can roughly be divided into direct and indirect approaches.

\section{Nonspecific direct cell labelling}

The most straightforward approach to cell labelling is the direct cell labelling method, where the label is added to the culture dish of cultured cells for "spontaneous" uptake of the label by the cells. The efficacy of this labelling method is strongly dependent on cell-specific properties. Cells that normally fulfil a function as scavenger or antigenpresenting cell (e.g. dendritic cells) generally show good incorporation of the label via the direct labelling method. Other types of cells, however, show a large variation in incorporation efficiency [108]. The advantage of direct cell labelling is that there are no additional agents or 

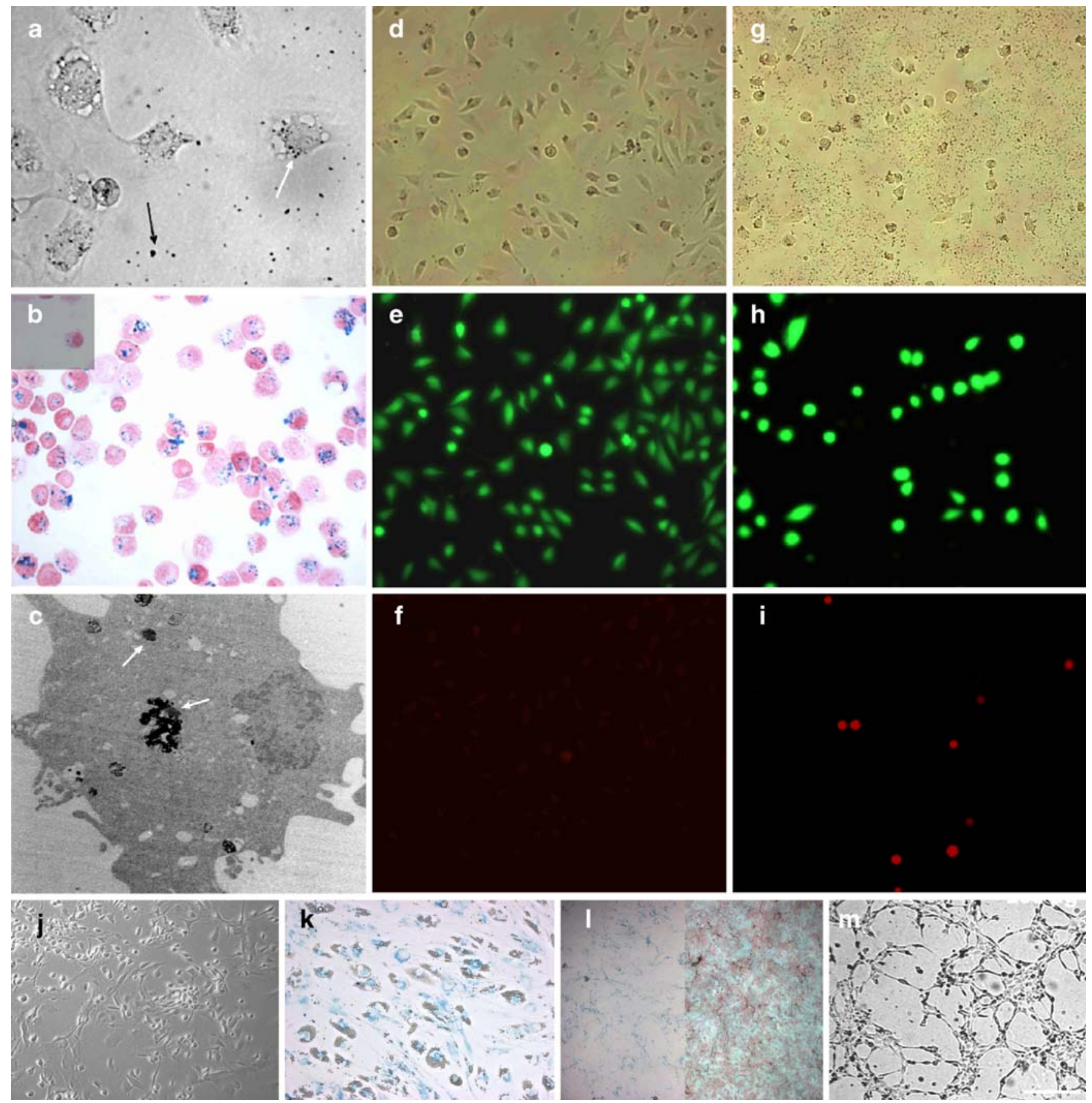

Fig. 1 Labelling efficiency of cells with iron oxide. a Stem cells in a culture dish with iron oxide-Lipofectamine complexes sedimented on the bottom of the culture dish (black arrow) and inside cells (white arrow). b Prussian blue-stained cell showing presence of iron oxide particles in the cell. c Electron microscopy image showing iron oxide particle complexes in intracellular vesicles. d-i LIVE/ DEAD assay, using calcein and ethidium homodimer-1, of ironlabelled cells at two labelling doses with iron oxide of $200 \mu \mathrm{g}(\mathbf{d}-\mathbf{f})$ and $800 \mu \mathrm{g}(\mathbf{g}-\mathbf{i})$. Panels $\mathbf{d}$ and $\mathbf{g}$ show regular bright field microscopy images; $\mathbf{e}$ and $\mathbf{h}$, green probe for living cells; and $\mathbf{f}$ and $\mathbf{i}$,

red probe for dying cells. Note the decrease in the number of cells at the higher labelling dose and the increase in dying cells. j Mesenchymal stem cells in culture. $\mathbf{k}$ Labelled mesenchymal stem cells after differentiation into fat cells stained for iron content with Prussian blue. Note the clearly visible fat vacuoles. I Labelled mesenchymal stem cells after differentiation into bone cells: left panel stained for iron by Prussian blue, right panel stained for bonespecific markers. m Tube forming of iron oxide-labelled endothelial cells on Matrigel 
manipulations needed. Furthermore, this technique can not only be used in vitro but also in vivo for phagocytic cells, macrophages, dendritic cells and cells from the reticuloendothelial system. These cells easily incorporate the contrast agents as they are capable of phagocytosing large particles easily or they are capable of incorporating small particles through pinocytosis. In vivo direct nonspecific cell labelling is currently used to visualise Kupffer cells in liver tissue, for lymph node imaging and for inflammatory cells [57]. It allows cell-specific imaging in different organs, but provides nonspecific labelling of all cell types that take up the agent.

\section{Nonspecific indirect cell labelling}

To improve the efficacy of cell labelling with contrast agents for various cell types, different so-called transfection reagents have been used. Transfection-mediated endocytosis is suitable for all cell types and has a high efficiency of label incorporation. This method is more laborious than spontaneous endocytosis and there can be toxicity of the transfection agent. There are many transfection agents available, each with their own potential benefits and drawbacks. The transfection reagents will form complexes with the contrast agents.
Lipofectamine (Invitrogen, Carlsbad, CA, USA) is a commonly used lipid-based transfection reagent, with high transfection efficiency for a wide range of cell lines [110]. The positive charge on the cationic lipids helps to bind the complexes to the cell membrane, after which the complexes enter the cell via endocytosis. Lipofectamine has been used as an additive in cell labelling studies for a large variety of cell types and successful protocols for over 20 different cell lines are available (Table 1). However, lipofectamine can only be used for cells that adhere to culture dishes. Therefore, other transfection reagents are needed to label cells in suspensions, such as the transfection agents DMRIE-C (Invitrogen, Carlsbad, CA, USA) or FreeStyle ${ }^{\mathrm{TM}}$ MAX (Invitrogen, Carlsbad, CA, USA). The DMRIE-C transfection agent gives a good performance for transfection of cells in suspension such as lymphoid cell lines. The FreeStyle ${ }^{\mathrm{TM}} \mathrm{MAX}$ Reagent is a proprietary, animal-origin-free formulation for the highly efficient transfection of eukaryotic cells in suspension [111].

The transfection agent poly-L-lysine (PLL) is also a commonly used agent for intracellular labelling [112]. The positively charged PLL is used to allow the cells to adhere with the cell membrane to negatively charged glass slides. This mechanism of charge-related binding is similar to the encapsulation of PLL-iron oxide complexes that will bind

Table 1 Methods for improved efficacy of contrast agent uptake

\begin{tabular}{|c|c|c|c|c|c|}
\hline & Name & Cell type & Efficiency & Disadvantages & Advantages \\
\hline 1 & $\begin{array}{l}\text { Lipofectamine }{ }^{\mathrm{TM}}[9,22,53, \\
171]^{\mathrm{a}}\end{array}$ & Adherent $^{\mathrm{b}}$ & High & Slightly toxic to cells & $\begin{array}{l}\text { Widely used } \\
\text { Simple protocol }\end{array}$ \\
\hline 2 & $\begin{array}{l}\text { Poly-L-lysine }[18,51,77 \text {, } \\
\text { 172, 173] }\end{array}$ & $\mathrm{All}^{\mathrm{c}}$ & High & $\begin{array}{l}\text { Slightly toxic to cells } \\
\text { Large variation in formulations available }\end{array}$ & $\begin{array}{l}\text { Widely used } \\
\text { Simple protocol }\end{array}$ \\
\hline 3 & $\begin{array}{l}\text { Magnetodendrimer }[12,13 \text {, } \\
174,175]\end{array}$ & Adherent & High & $\begin{array}{l}\text { Slightly toxic to cells } \\
\text { Not widely available }\end{array}$ & $\begin{array}{l}\text { Uptake is similar for different } \\
\text { cell types }\end{array}$ \\
\hline 4 & $\begin{array}{l}\text { Protamine sulfate }[7,21,49 \text {, } \\
176]\end{array}$ & Adherent & High & $\begin{array}{l}\text { Heparin anticoagulant } \\
\text { Tendency to form large aggregates }\end{array}$ & $\begin{array}{l}\text { FDA-approved agent } \\
\text { Simple protocol }\end{array}$ \\
\hline 5 & HIV-1 tat $[17,66,177-179]$ & Adherent & High & $\begin{array}{l}\text { Possibility of undesirable immune response } \\
\text { Potential nuclear localisation of contrast } \\
\text { agent } \\
\text { Prior chemical linkage to contrast agent } \\
\text { necessary }\end{array}$ & Fast labelling procedure \\
\hline \multirow[t]{2}{*}{6} & $\begin{array}{l}\text { Electroporation }[11,24,180 \text {, } \\
181]\end{array}$ & All & Low & Technically challenging & $\begin{array}{l}\text { Can be used for difficult-to- } \\
\text { transfect cells }\end{array}$ \\
\hline & & & & Specialised equipment needed & $\begin{array}{l}\text { Cytoplasmic localisation of small } \\
\text { molecules }\end{array}$ \\
\hline 7 & Gene gun $[119,120,182]$ & All & Low & Specialised equipment needed & None \\
\hline
\end{tabular}

${ }^{\mathrm{a}}$ Reference papers

${ }^{\mathrm{b}}$ Cells growing in culture adhered to the bottom of the culture dish

${ }^{c}$ Cells growing in culture adhered to the bottom of the culture dish as well as in suspension 
to the target cells resulting in uptake of iron oxide nanoparticles (Table 1).

Magnetodendrimers [13] (Table 1) can enter the cell through a nonspecific membrane adsorption process after which the contrast agent will be localised in intracellular (non-nuclear) endosomes. Regardless of which cell type is used, transfection with magnetodendrimers shows a comparable degree of particle uptake. A high level of transfection is accomplished by using the heat-activated dendrimer SuperFect (Qiagen, Valencia, CA, USA) [12].

Protamine sulfate [49] (Table 1) can be used to get a contrast agent into the cell by endosome formation. The advantage of protamine sulfate is that it is an FDAapproved agent used as an antidote to heparin. However, in gene therapy protocols, protamine sulfate is commonly used for in vitro transfection [113]. Protamine sulfate combined with the FDA-approved Feridex shows potential for clinical application.

The peptide HIV-1 tat (derived from the trans-activating protein of the human immunodeficiency virus type-1) can also be used to internalise contrast agents (Table 1) [114]. This method is not dependent on a receptor, but translocates exogenous molecules into cells. Cross-linked with iron oxide particles the HIV-1 tat particles allow cell detection with MRI. The HIV-1 tat peptide is the only transfection agent that has been detected within the cell nucleus [17].

Contrast agents can also enter the cell via electroporation [115] (Table 1). This can work well for cell types that are difficult to transfect with commonly used transfection agents. An electrical pulse creates a potential difference across the cell membrane and induces temporary pores in the cell membrane for the entry of the contrast agents. Depending on the type of contrast agent used, this will result in endosomal entrapment of the contrast agent (nanoparticles) in the cell [115] or localisation of the contrast agent in the cytoplasm (small molecules) [116]. Although no additional reagents are necessary for electroporation, specialised equipment is needed and the procedure is technically challenging. It requires optimisation of electrical pulse and field strength parameters [117]. Furthermore, there is a large variation in cell tolerance as high toxicity levels are observed after electroporation. It can irreversibly damage the membrane and lyse the cells. Cell survival after labelling is usually not above 70\% [118].

Another method of nonspecific cell labelling is by using a gene gun (Table 1) [119, 120]. Gene guns were developed to introduce genetic material into tissues, cells or organelles [121]. It can also be used to introduce nanoparticles, including MRI contrast agents, into cells. The material of interest is "shot" into cells of the recipient using pressurized helium that launches a disk carrying the nanoparticles. This disk travels at the speed of a rifle bullet, and hits a screen, which detains the disk, but launches the microscopic particles towards the target cells.
There are no specific benefits described that favour the use of a gene gun for cell labelling. The technique needs specialised equipment and the efficacy of cell labelling is difficult to manipulate. Furthermore, the potential adverse effects are not yet known.

\section{Specific cell labelling in vitro}

The major advantage of specific cell labelling is that it allows labelling of specific cells in a mixed cell population. In vitro labelling can be established by using a targeting vector, such as antibodies, peptides, aptamers, amino acids and lectines conjugated to the contrast agent $[14,72,122-$ 124]. These vectors will bind specifically to target molecules/receptors on the cells of interest. Compared with regular endocytosis, there is increased efficiency [19]. However, it needs previous knowledge of the expression of the target molecule. Furthermore, there needs to be chemical linkage of the label to the target molecule and attachment of the probe to the receptor. This chemical linkage of the ligand to the receptor could lead to unintended triggering of biochemical processes. Furthermore, depending on the effect of receptor-ligand binding, internalisation of the probe may not always occur. Without internalisation, it could be possible that the contrast agent might be rapidly cleared from the cell.

Other particles that can be used for cellular labelling are microbeads. Microbeads used for magnetic cell sorting can be used as a contrast agent linked to an antibody that is bound to the target cell [125]. The advantage of this labelling method is that the particles do not internalise, and therefore it is assumed that no toxic effects of the particle are exerted. Furthermore, it is not required to culture the cells, as labelling can be performed in a cell suspension. However, the attachment to the outer cell membrane is likely to interfere with cell-surface interactions, and unwanted activation of biochemical pathways, including apoptosis, can result. Furthermore, cell membrane labelling often does not result in sufficient signal for in vivo MR imaging, and as the particles do not internalise, the antibody might also easily detach and attach to other cells.

However, when labelling a complete cell population in vitro, an additional probe to select a subpopulation of cells is not needed and nonspecific labelling is preferred [126].

\section{Specific cell labelling in vivo}

The major advantage of specific in vivo cell labelling [127] is that there are no preceding cell harvesting procedures or any in vitro manipulations needed. Furthermore, one can choose to label cells at any given time point. However, the method faces an extra challenge because of the delivery 
barrier. There are several prerequisites for cell/tissuespecific contrast enhancement in vivo. First, there should be sufficient binding of contrast agent to the target cells. This can be achieved, for example, by antibodies [128]; however, there should not be any steric hindrance on the outside of the cell membrane if internalisation of the antibody does not occur. It should also always be kept in mind that the probe may be passed to other cells if the primary labelled cell dies and is endocytosed by macrophages [129]. Second, for organ imaging, overcoming the delivery barrier can be challenging, especially for neural imaging when the blood-brain barrier has to be crossed. Finally, most of the contrast agents that are nowadays used in clinical practice have a fast clearance after injection [130]. This does not allow a long follow-up with MRI.

\section{Labelling protocol}

A large variety of labelling methods have been described [131]. There are so many different protocols because each differs depending on which transfection agent is being used, as well as which contrast agent is chosen, and furthermore, which preferred labelling method is used i.e. specific, unspecific, in vitro or in vivo. Moreover, the relative dosage of contrast agents used to label cells, as well as the incubation time, varies strongly between studies. For example, the dosage for labelling cells with iron particles may vary from 1 to $2,800 \mu \mathrm{g} / \mathrm{ml}$. Furthermore, labelling times of between 1 and $72 \mathrm{~h}$ have been described [114, 132, 133]. The combined effect of labelling dose and labelling time determines labelling efficiency and/or toxicity, and depends on the cell type used. The labelling method used may influence the compartmentalisation of the probe within the cells, and consequently the fate/behaviour and toxicity of the probe. In vitro, it seems important to quantify the amount of label per surface area instead of the concentration of label in the fluid above the cells.

Not all contrast agents that are used to label cells are commercially available. Studies that use non-commercially available probes have their own manufacturing protocols. Therefore, not only the protocol used to label the cells may vary a lot, but also the method of preparing the desired paramagnetic nanoparticles. What should be kept in mind is that the preparation protocol of iron-coated particles, for example, will lead to different physiochemical properties.

\section{Labelling efficiency}

It is important to check the efficiency of cell labelling, as more label will in general lead to better visualisation with MRI. Labelling efficiency can be assessed by two different approaches, by evaluating how many cells are labelled or by assessing how much label is incorporated within the cells. It is very easy to look at the percentage of labelled cells of the population of interest. This can be done by counting the labelled cells under light, fluorescent or electron microscopy. However, to quantify the amount of contrast agent inside the cell, more laborious measurements need to be performed. It should be kept in mind that the labelling efficiency is dependent on many parameters such as cell type, labelling method and labelling protocol.

To visualise iron in the cells/tissue after labelling, Prussian blue [35] staining is a widely used and easy method. Using potassium ferrocyanide in acetic acid or by dilute mineral acid hydrolysis, ferric ions are released from protein-bound tissue deposits. The non-haemoglobin-bound iron reacts with potassium ferrocyanide to form potassium ferric ferrocyanide $\left(\mathrm{FeCl}_{3}+\mathrm{K}_{4} \mathrm{Fe}(\mathrm{CN})_{6} \rightleftharpoons \mathrm{KFe}\left[\mathrm{Fe}(\mathrm{CN})_{6}\right]+3 \mathrm{KCl}\right)$. This is an insoluble, blue compound known as Prussian blue (Fig. 1b). The intensity of the colour gives some indication as to the amount of iron $\left(\mathrm{Fe}_{3+}\right)$; however, other sources of iron besides $\mathrm{Fe}_{3}$ + will also have be to demonstrated. For example, $\mathrm{Fe}_{2+}$ ions do not produce a coloured reaction product and will therefore not be visualised by Prussian blue staining [134].

Another similar staining assay that can be used to quantify the amount of iron in the cells is the QuantiChrom iron assay [135]. This method utilises a chromogen that forms a blue complex specifically with $\mathrm{Fe}^{2+}$. The $\mathrm{Fe}^{3+}$ in the sample is reduced to $\mathrm{Fe}^{2+}$, and therefore the assay will measure total iron concentration. The intensity of the colour, measured by light spectrophotometry, is directly proportionate to the iron concentration in the sample.

By performing atomic absorption spectrophotometry the amount of iron can also be quantified [136]. In order to analyse for any given element, a lamp is chosen that produces a wavelength of light that is absorbed only by that element. The technique usually uses a flame to atomise the sample. The electrons of the atoms in the flame can be promoted to higher orbitals by absorbing energy. This amount of absorbed energy is specific to the particular electron transition in a particular element. If any ions of the given element are present in the flame, they will absorb light produced by the lamp before it reaches the detector. As the quantity of energy put into the flame is known, and the quantity remaining can be measured, it is possible to calculate how many of these transitions took place. Therefore, the amount of light absorbed depends on the amount of the element present in the sample. The signal obtained is proportional to the concentration of the element that was measured.

Inductively coupled plasma mass or optical emission spectroscopy (ICP-MS or ICP-OES) can be used to quantify the amount of contrast agent (gadolinium or iron for example) in the cells/tissue after labelling [13, 40, 137]. Inductively coupled plasma spectroscopy is based on optical emission spectroscopy. Emission spectroscopy is a technique that examines the wavelengths of photons emitted by molecules during their transition from an excited state to a lower energy state. Each element emits a 
characteristic set of wavelengths according to its atomic structure; by observing and quantifying these wavelengths the elemental composition can be determined.

With nuclear MRI relaxation, labelling efficiency can also be determined [13, 40, 137]. There are differences in relaxation times between for example tissue and labelled cells; therefore, with NMRI, the spin relaxation can be measured. T1 relaxation refers to nuclei that return to the thermodynamic state in the magnet. $\mathrm{T} 2$ relaxation refers to precessing nuclei that fall out of alignment with each other and stop producing a signal. The sensitivity of the technique depends on the strength of the magnetic field.

\section{Toxicity assessment}

For molecular and cellular imaging, nontoxic biocompatible contrast agents are needed to safely and effectively use MRI for cell tracking. To measure toxicity in vitro, cell survival, cell proliferation and/or cell function have to be monitored. A variety of assays are available to assess potential adverse effects.

\section{Cell survival}

Cell viability can be defined as the number of healthy cells in a sample. Whether the cells are actively dividing or functioning is not distinguished. Cell survival can be assessed in several different ways (Table 2). For example, using light microscopy by counting the number of cells and using trypan blue exclusion [138] (Table 2). Trypan blue is a negatively charged chromophore that only interacts with nonviable cells. In this assay, cell viability is measured by the ability of cells with uncompromised membrane integrity to exclude the dye. This assay is very simple and cheap. However, each individual sample must be counted and it only stains necrotic or very late apoptotic cells.

Using spectrophotometry the conversion of tetrazolium salts into formazan can be measured (Table 2) [139]. Formazan is a light-absorbing product formed by reduction of tetrazolium salts in mitochondria. This reduction takes place only when mitochondrial enzymes are active, and therefore the amount of formazan formed can be directly related to the number of living cells. However, one has to keep in mind that under nonideal cell culture conditions, mitochondrial metabolism may vary greatly because of the metabolic state of the cells [139]. The measurement obtained should therefore always be compared with unlabelled controls. There are several commercial kits available for measuring metabolic conversion of tetrazolium salts into formazan, e.g. MTT assay, XTT assay and WST-1 assay. MTT (3-(4,5-dimethylthiazol-2-yl)-2,5diphenyltetrazolium bromide) is an inexpensive assay and MTT is metabolised by all cells into formazan crystals that have to be solubilised before measurement. However, cells with low metabolic activity must be used in high numbers. XTT and WST-1 are tetrazolium salts that form soluble formazan products; however, they are not metabolised by all cell types.

With fluorescence microscopy the exclusion of a fluorescent vital dye can be assessed. Fluorescent vital dyes, like ethidium homodimer-1 or propidium iodide, only enter nonviable cells [140] (Fig. 1d-i). The propidium iodide exclusion assay (Table 2) is a quick and cheap assay method to distinguish viable from dead cells by fluorescence microscopy and flow cytometry. The interaction of the fluorescent vital dye or apoptosis marker with the cell can be assessed. Only a small fraction of total cells from a cell population is required; however, each individual sample must be counted.

Table 2 Assays for assessing cell survival/cell viability

\begin{tabular}{|c|c|c|c|c|}
\hline & Name & Biological principle & Advantages & Disadvantages \\
\hline 1 & $\begin{array}{l}\text { Trypan blue exclusion assay } \\
{[8,10,114]^{\mathrm{a}}}\end{array}$ & $\begin{array}{l}\text { Cytoplasmic membrane } \\
\text { integrity }\end{array}$ & $\begin{array}{l}\text { Simple } \\
\text { Inexpensive }\end{array}$ & $\begin{array}{l}\text { Laborious } \\
\text { Stains only necrotic or late apoptotic cells }\end{array}$ \\
\hline $2 \mathrm{a}$ & MTT assay $[7,21]$ & Metabolic activity & $\begin{array}{l}\text { Detects living cells } \\
\text { Suitable for all cell types } \\
\text { High throughput }\end{array}$ & Signal is dependent on cell activation \\
\hline $2 b$ & XTT assay/WST-1 assay [5] & Metabolic activity & $\begin{array}{l}\text { Detects living cells } \\
\text { High throughput } \\
\text { Fast assay }\end{array}$ & $\begin{array}{l}\text { Signal is dependent on cell activation } \\
\text { Not metabolized by all cell types }\end{array}$ \\
\hline 3 & $\begin{array}{l}\text { Propidium iodide exclusion } \\
{[7,9,114]}\end{array}$ & $\begin{array}{l}\text { Cytoplasmic membrane } \\
\text { integrity }\end{array}$ & $\begin{array}{l}\text { Simple } \\
\text { Inexpensive } \\
\text { High throughput }\end{array}$ & Toxic compound (health hazard) \\
\hline
\end{tabular}

${ }^{\mathrm{a}}$ Reference papers 
Some of the assays used for the assessment of cell survival provide indirect measures of cell survival. For each assay, calibration/validation of the assay for the specific cell type or assay conditions is required, otherwise false positive or false negative results may be obtained, e.g. reduction of tetrazolium into formazan by mitochondria is used as a measure of cell number. The rate of mitochondrial metabolism may, however, change without a corresponding change in cell number.

\section{Cell proliferation}

Cell proliferation is the measurement of the number of cells that are dividing in a culture as well as the speed of cell division. Cell proliferation can also be assessed using different techniques (Table 3). One way of measuring proliferation is by performing clonogenic assays [141]. A defined number of cells are plated on culture dishes in low densities and the numbers of colonies that are formed after a period of growth are counted. Drawbacks to this method are that it is laborious and therefore not practical for large numbers of samples. In addition, if cells divide only a few times and then become quiescent, colonies may be too small to be counted and the number of dividing cells may be underestimated. Alternatively, growth curves could be established by repeated counting of the number of cells over time by light microscopy (Table 3), which is also timeconsuming and laborious [22].

A commonly used assay to measure proliferation is the MTT assay. As with the assessment of cell viability, the amount of formazan formed can be directly related to the number of cells. In order to assess cell proliferation, growth curves have to be generated from repeated measures over time. Again, one has to keep in mind that under nonideal cell culture conditions, the metabolic state of the cells and thus formazan formation may vary greatly [139].

Alamar Blue (Table 3) is a safe, nontoxic aqueous dye that is used to assess cell viability and cell proliferation [142]. Because the Alamar Blue assay requires a very simple measurement, it does allow continuous monitoring of cells even after the measurement. Alamar Blue consists of an oxidation-reduction (redox) indicator that yields a colorimetric change and a fluorescent signal in response to a metabolic activity. The extent of conversion is a reflection of cell viability and it can be quantified by its optical density or by fluorescence for greater sensitivity [142].

Cell proliferation can also be monitored by assessing DNA synthesis. The two most commonly used assays are $\left[{ }^{3} \mathrm{H}\right]$ thymidine incorporation [143] and (5-bromo-2'deoxyuridine) incorporation [144] (Table 3). During the $S$ phase of cell division the cell undergoes DNA synthesis and replicates its genome. Addition of $\left[{ }^{3} \mathrm{H}\right]$ thymidine or

Table 3 Assays for assessing proliferation

\begin{tabular}{|c|c|c|c|c|}
\hline & Name & Based on & Advantages & Disadvantages \\
\hline 1 & Cell counting $[182]^{\mathrm{a}}$ & Actual cell number & $\begin{array}{l}\text { Simple } \\
\text { Inexpensive } \\
\text { Actual cell numbers determined }\end{array}$ & $\begin{array}{l}\text { Laborious } \\
\text { Large number of cells needed }\end{array}$ \\
\hline 2 & MTT assay $[7,21]$ & Metabolic activity & $\begin{array}{l}\text { High throughput } \\
\text { Sensitive (requires only a few cells) }\end{array}$ & $\begin{array}{l}\text { Signal is dependent on cell activation } \\
\text { Separate samples per time point needed }\end{array}$ \\
\hline 3 & $\begin{array}{l}\text { XTT assay/WST-1 } \\
\text { assay [5] }\end{array}$ & Metabolic activity & $\begin{array}{l}\text { High throughput } \\
\text { Sensitive (requires only a few cells) } \\
\text { Short period of incubation }\end{array}$ & $\begin{array}{l}\text { Signal is dependent on cell activation } \\
\text { Not metabolized by all cell types } \\
\text { Separate samples per time point needed }\end{array}$ \\
\hline 4 & $\begin{array}{l}\text { Alamar Blue }{ }^{\circledR} \\
\text { assay }[183]\end{array}$ & Metabolic activity & $\begin{array}{l}\text { High throughput } \\
\text { Sensitive (requires only a few cells) } \\
\text { Allows continuous/longitudinal } \\
\text { monitoring }\end{array}$ & High sensitivity to buffer conditions \\
\hline 5 & $\begin{array}{l}{\left[{ }^{3} \mathrm{H}\right] \text { Thymidine }} \\
\text { incorporation assay }\end{array}$ & DNA synthesis & $\begin{array}{l}\text { High throughput } \\
\text { Sensitive (requires very few cells) }\end{array}$ & Radioactive \\
\hline 6 & $\begin{array}{l}\text { BrdU incorporation } \\
\text { assay [184] }\end{array}$ & DNA synthesis & $\begin{array}{l}\text { High throughput } \\
\text { Sensitive (requires very few cells) }\end{array}$ & $\begin{array}{l}\text { Radicalization may itself lead to sister } \\
\text { chromatid exchanges }\end{array}$ \\
\hline 7 & CFSE assay & Protein binding & $\begin{array}{l}\text { High throughput } \\
\text { Longitudinal measurements possible } \\
\text { Different populations within one } \\
\text { sample can be monitored }\end{array}$ & Weak fluorescence after long culture time \\
\hline
\end{tabular}

\footnotetext{
${ }^{\mathrm{a}}$ Reference papers
} 
bromodeoxyuridine (BrdU) to the culture medium provides a way to assess DNA replication. $\left[{ }^{3} \mathrm{H}\right]$ Thymidine is a radioactive compound and the amount of thymidine incorporated into DNA is determined either by measuring the total amount of labelled DNA in a population, or by detecting the labelled nuclei microscopically. It is a sensitive assay that allows linear measurement of cell proliferation over a broad, logarithmic range. However, a big disadvantage is that the radioactive isotope has a long half-life.

Incorporated BrdU can be visualised by using a monoclonal antibody against BrdU (Table 3). BrdU incorporation and/or distribution can also be measured by colorimetric or chemiluminescent immunoassays. The colorimetric measurement is less sensitive than a chemiluminescence measurement, and it does not allow linear measurement of cell proliferation. It should be noted that the ability to detect a minimum number of proliferating cells depends on the amount of BrdU incorporated into the cells and thus on the labelling period. In most cases, detection requires a labelling period of 2 to $24 \mathrm{~h}$. However, the assay is quite simple.

Carboxyfluorescein diacetate succinimidyl ester (CFSE) is a fluorescent molecule that divides equally over daughter cells, enabling visualisation of cell division [145] (Table 3). When CFSE-labelled cells divide, the intensity of their fluorescence is halved with each successive cell division and therefore a final fluorescence measurement corresponds to the number of divisions the cells have undergone.

When assessing cell proliferation there are potential pitfalls. Similar to assays of cell survival, most assays used are indirect measures of cell proliferation and calibration/ validation of the assay is required. Therefore, different outcomes of toxicity assessment with identical cell labelling protocols can be obtained with different assays [9].

\section{Cell function}

Besides evaluating cell survival and cell proliferation after cell labelling, the third and very important requirement for assessing toxicity is measurement of cell function. To assess primary cell function cytokine production $[19,71$, 137] (Table 4), cytolytic activity or tube forming capacity $[9,146]$ (Table 4) can be evaluated. Furthermore, the differentiation potential $[40,49,51,53]$ (Table 4) and the capacity to migrate or home $[15,40]$ (Table 4) to appropriate target tissues can be tested. In general, although all the assays described provide complementary information about cell function, not all tests are relevant for every cell type and testing one of the assays described is enough to make a general statement about cell function after labelling.

Cytokines are proteins that are used extensively in cellular communication and play an important role in the development and functioning of the immune system, in various pathologic processes and are also involved in several developmental processes during embryogenesis. Cytokine production can be measured in the supernatant of cultured cells by using cytokine ELISA plates [129]. These are sensitive enzyme immunoassays that can specifically detect and quantify the concentration of soluble cytokine and chemokine proteins; however, they do not provide information concerning the biological potency of the proteins detected.

Cellular differentiation is a complex process involving growth arrest, exit from the cell cycle and expression of differentiated cell-type-specific functions. Especially when using stem cells, it is important that the labelling procedure does not affect their ability to differentiate after injection in vivo [53]. In differentiation assays cells are cultured in a special medium containing specific growth factors that induce cellular differentiation. After several days or weeks the differentiation of the cells into a specific lineage can be confirmed and/or assessed by looking at the cell phenotype, the morphological appearance and the expression of cell lineage markers or specific receptors, using lineagespecific dyes or antibodies (Fig. 1j-1).

Angiogenesis is altered as a result of certain diseases such as cancer, diabetic retinopathy and rheumatoid arthritis, which results in excessive or insufficient blood vessel formation. Tube formation is a multistep process involving cell adhesion, migration, differentiation and growth that is very important in angiogenesis. Tube formation capacity

Table 4 Assays for assessing cell function

\begin{tabular}{llll}
\hline & Functional capacity & Most relevant for & Limitations and pitfalls $^{\mathrm{b}}$ \\
\hline 1 & Cytokine production $[19,71,137]^{\mathrm{a}}$ & Haematopoietic lineage cells & Biological potency of cytokines undetermined \\
2 & Tube formation capacity $[9,146]$ & Stem cells & Quantification difficult \\
& & Endothelial precursor cells & \\
3 & Cellular differentiation $[49,51,53]$ & Stem cells & Lengthy assay (cell culture may take up to weeks) \\
4 & Cell migration $[15,40]$ & Haematopoietic lineage cells & No discrimination between chemotaxis or chemokinesis \\
& & Stem cells & \\
\hline
\end{tabular}

${ }^{\text {a }}$ Reference papers

${ }^{b}$ Cell types for which the listed functional capacity is most central or essential 
can be measured with a so-called Matrigel assay [147]. Matrigel is a solubilised basement membrane preparation that is rich in proteins. The major components are laminin, collagen and growth factors. It is mainly used for cell invasion and tube formation assays. The tube formation assay is based on the ability of cells to form 3D capillarylike tubular structures when cultured on the gel of basement membrane extract (Fig. 1h). Quantification can be performed by manually counting the number of cell clusters and branching under the microscope or automatically with software. However, quantification is not easy because of the complex 3D structures that are formed.

Cell migration is crucial for several processes within the human body such as embryonic development, the inflammatory immune response, wound repair, tumour formation and metastasis. One of the most frequently used in vitro assays to assess cell migration capacity is the filter assay. The assay involves a two-compartment system where cells may be induced to migrate from an upper compartment through a membrane with small pores into a lower compartment [148]. The assay is based on a chemotactic response of cells. However, chemotaxis, which is directed movement, and chemokinesis, which is an undirected increase in migratory activity, cannot be discriminated with this assay. This is because an equilibrium of the chemoattractant between the two compartments will eventually be formed. Cell migration through the membrane can be measured by staining and quantifying the cells that attach to the other side of the membrane.

\section{Image acquisition}

An MRI machine is a versatile imaging system that can integrate a broad range of specialised applications, providing a wide basis for the diagnosis, staging or monitoring of pathological conditions or biological processes, including cell imaging. Its versatility, however, also makes it complex and many factors may influence the information obtained during image acquisition.

\section{MR field strength}

In vivo imaging of iron-labelled cells has been demonstrated at magnetic field strengths ranging from $0.5 \mathrm{~T}$ to $17 \mathrm{~T}$ (Table 5). In MR imaging, signal-to-noise (SNR) is proportional to the magnetic field strength, as well as the spatial resolution or imaging time. MR systems with higher magnetic field strengths therefore offer advantages over MR machines with lower field strengths. Nonetheless, it must be kept in mind that higher magnetic field strengths require faster signal sampling to counteract the dramatically increased $\mathrm{T}_{2} *$ shortening, e.g. at any air-tissue interface (heart-lung, bowel etc.).

For cell imaging, higher field strength also appears to be beneficial. Reported detection limits of iron-labelled cells are lower at higher magnetic field strengths because of increased susceptibility effects [149]. This higher detection sensitivity may, however, depend on the anatomical context of the labelled cells. At higher field strengths the $\mathrm{T} 1$ relaxation of tissue lengthens and $\mathrm{T} 2 *$ shortens and chemical shift effects may increase, each of which in turn may decrease the conspicuity of iron-labelled cells.

It is unclear whether or not higher magnetic field strengths are also beneficial for cell imaging using Gdbased contrast agents. Commercial, Gd-based contrast agents generally have low relaxivity, which becomes even less at higher magnetic field strengths, leading to reduced sensitivity [150]. Nonetheless, success with Gd-labelled cells at high magnetic field strength has been reported $[5,151]$.

Besides some potential benefits of high magnetic field strengths in cell imaging, the management of higher heat deposition may become problematic, especially if cell imaging/tracking is to be performed effectively in humans. The specific absorption rate (SAR) greatly limits acquisition speed in order to keep heat deposition limited at high magnetic field strengths. Even for applications in animals, there will also be limits that have to be respected. The most frequently used imaging strategies for iron-labelled cells involve $\mathrm{T} 2 *$-weighted protocols employing gradient-

Table 5 In vivo cell imaging at various field strengths

\begin{tabular}{lllll}
\hline Magnetic field strength (T) & Cell type & Contrast agent & Target organ (species) & Reference \\
\hline 0.5 & MSC & Ferumoxide & Heart (rat) & {$[52]$} \\
1.5 & MSC & Ferumoxide & Kidney (rat) & {$[152]$} \\
3.0 & MSC & Ferucarbotran & Kidney (rat) & {$[154]$} \\
4.7 & Oligodendrocyte PC & MION & Spinal cord (rat) & {$[153]$} \\
7.0 & Embryonic SC & Ferumoxtran & Brain (rat) & {$[10]$} \\
9.4 & T cells & CLIO & Spleen (mouse) & {$[185]$} \\
11.7 & Dendritic cells & SPIO & Skeletal muscle (mouse) & {$[137]$} \\
17.6 & Embryonic SC & VSOP & Brain (rat) & {$[186]$} \\
\hline
\end{tabular}

$M S C$ mesenchymal stem cell, $P C$ precursor cell, $S C$ stem cell, $M I O N$ monocrystalline iron oxide nanoparticles, $C L I O$ cross-linked iron oxide, SPIO superparamagnetic iron oxide, VSOP very small superparamagnetic iron oxide particles 
recalled echo (GRE) sequences. Such imaging strategies are not radiofrequency (RF) intensive (low flip angle regime). However, steady-state free precession (SSFP) sequences (using high flip angles with short repetition times, TR) on the other hand, are SAR intensive. Also, T1weighted protocols that may be used in the future with cells labelled with contrast agents providing short $\mathrm{T} 1$ relaxation times are SAR intensive.

\section{MR imaging hardware}

Generally, higher magnetic field strengths are being used to improve the balance among SNR, resolution and imaging time. Alternatively, SNR can be improved by using better performance (multichannel) receiver systems. Small loop coils with a diameter of less than $1 \mathrm{~cm}$ make it possible to image single labelled cells in vitro (single cell level detection with positive or negative contrast) at voxel sizes in the order of $40 \times 40 \times 100 \mu^{3}$ and acquisition times of less than $30 \mathrm{~min}$ even at $3.0 \mathrm{~T}$ [9]. To provide optimal image quality over larger fields-of-view phased-arraycombined small surface coils can be used. Generally, these are more effective than volume coils for providing optimal SNR. The gain in imaging speed that is possible with the smaller coils can be traded effectively for higher in-plane and through-plane resolution in molecular imaging applications. It must nonetheless be kept in mind that the smaller the loop coil diameter is, the less the sensitivity volume will be; signal reception (sensitivity volume) is limited to about the radius from the surface coil.

\section{MR sequences}

Different acquisition sequences allow manipulation of contrast mechanisms and possibilities for signal amplification strategies for cell imaging in conjunction with detailed anatomical and functional information. Tissue contrast can be generated mainly through differences in proton density and relaxation times ( $\mathrm{T} 1$ and $\mathrm{T} 2$ ) by adjusting the MR pulse sequence timings to provide a suitable contrast to distinguish target structures. Imaging of iron-labelled cells is commonly performed using T2- and T2*-weighted imaging employing gradient echo or spinecho sequences [7, 10, 15, 114, 132, 152-154] (Fig. 2d). For Gd-labelled cells T1-weighted spin-echo sequences are most commonly used [5, 14, 39, 116, 151] (Fig. 2); however, T2-weighted spin-echo sequences may also be employed $[8,155]$. Which type of contrast weighting will be most beneficial for the imaging of Gd-labelled cells may depend on the local $\mathrm{Gd}$ concentration or potentially the intracellular compartmentalisation of the $\mathrm{Gd}[40,116]$.

Improved detection sensitivity of labelled cells may be obtained with the more sophisticated steady-state free precession (SSFP) imaging techniques, also known as
FIESTA or True FISP [20, 48, 155-159]. However, it must be taken into account that with SSFP images, contrary to the more conventional spin-echo or gradient-recalled echo sequences, high resolution imaging at reasonable image quality is difficult to achieve (off-resonance effects on signal behaviour) on clinical imaging equipment unless more potent (customised) gradient insert coils are used.

Recently, new acquisition approaches have been pursued to generate positive contrast from traditionally 'negative contrast' materials such as iron oxide nanoparticles [160163]. In in vivo applications it sometimes proved to be difficult to identify the presence of iron-labelled cells due to the presence of other hypointense regions. In order to facilitate the detection of iron-labelled cells in such regions, investigators have used spectrally selective RF pulses to excite and refocus water off-resonance in regions near the labelled cells to obtain positive contrast $[160,163]$. Alternatively, so-called white marker imaging has been implemented, in which traditional GRE sequences are modified to include a variable dephasing gradient, also resulting in positive contrast [161, 162].

\section{Unsolved issues}

While cell imaging by MRI has already carefully entered the clinical arena, several challenges still need to be met in order to turn cell imaging by MRI into a robust technique either in experimental settings or clinical applications. These challenges comprise the ability to quantify the number of labelled cells, the ability to distinguish viable iron-labelled cells from other sources of iron or susceptibility artefacts in tissue and the assessment of long-term effects of intracellular contrast agents in terms of toxicity.

For the development and validation of cell-based therapeutic strategies, quantification of the number of cells, homing to or residing in the target organs, is of crucial importance. For iron-labelled cells quantification of cell numbers is feasible under controlled (in vitro) conditions, using T2- or T2*-mapping approaches [164, 165]. However, robust in vivo quantification using such MR relaxometry approaches is hampered by a variety of factors: variations in tissue $\mathrm{T} 2$ and $\mathrm{T} 2 *$ values as a result of field inhomogeneities, and physiological status [165], density distribution of labelled cells [166] and changes in intracellular iron loads as a result of cell division or iron metabolism [166]. Several potential solutions to overcome these complicating factors have been proposed and are currently under investigation $[4,107,149]$.

The signal changes caused by labelled cells in vivo are unfortunately not unique features. Areas with signal loss or signal gain similar to that produced by labelled cells can also arise from various (patho)physiological conditions such as: deposits of haemosiderin, blood flow and airtissue interfaces. Identification of labelled cells in or near such areas may therefore be impossible. The use of tailored 

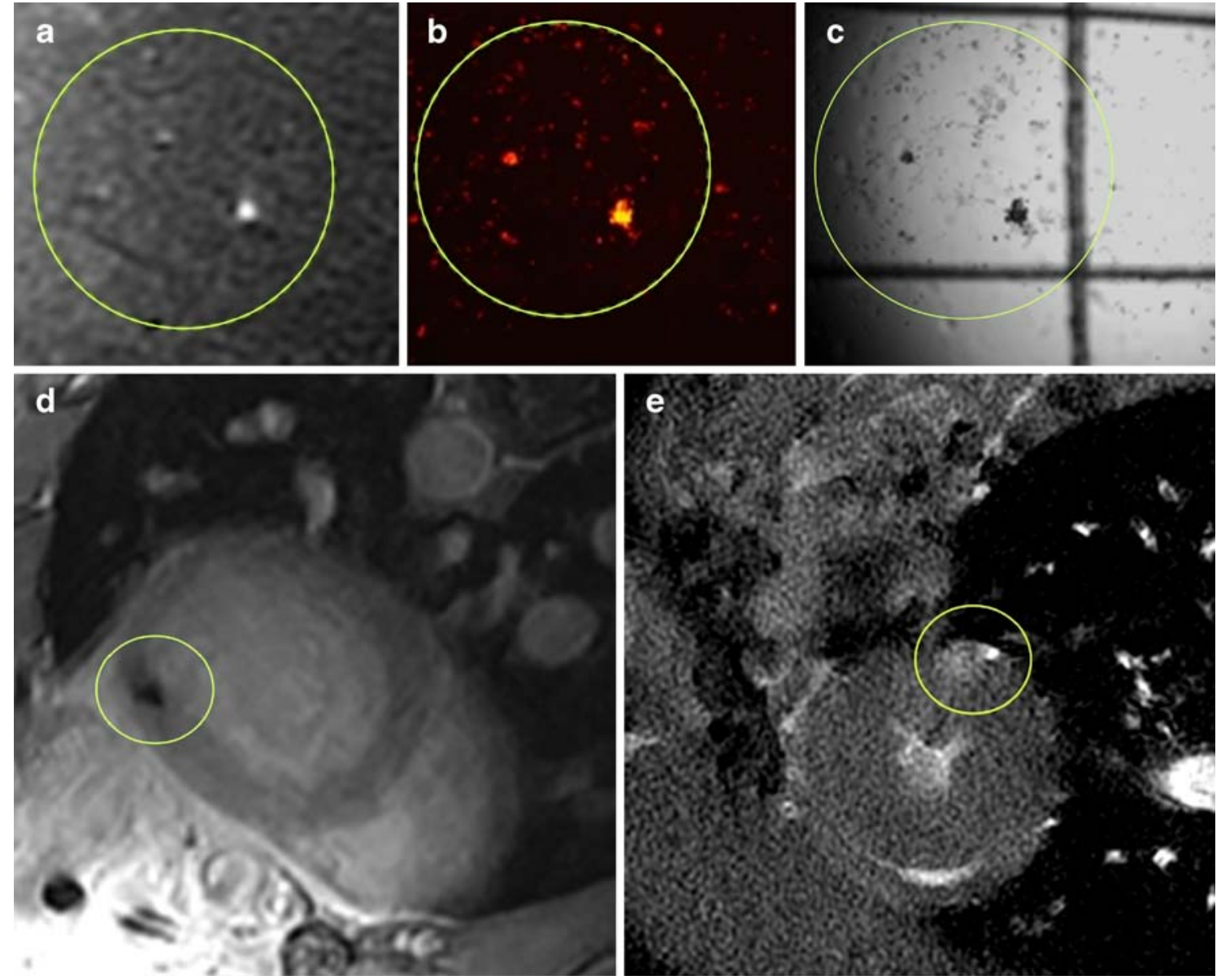

Fig. 2 Magnetic resonance imaging of paramagnetically labelled cells. a-c Stem cells in a culture dish labelled with fluorescent nanoparticles containing Gd-DTPA, imaged by MRI (a), fluorescent microscopy (b) and light microscopy (c). Acquisition parameters for MRI: 3D-SPGR sequence with TE $=3.0 \mathrm{~ms}, \mathrm{TR}=31.0 \mathrm{~ms}, \alpha=50^{\circ}$ and resolution $142 \times 142 \times 100 \mu^{3}$. d MR image of stem cells labelled with iron oxide particles, injected into the myocardium of a rat heart. Acquisition parameters for MRI: 2D CINE GRE sequence with $\mathrm{TE}=4.5 \mathrm{~ms}, \mathrm{TR}=18.0 \mathrm{~ms}, \alpha=18^{\circ}$ and resolution $156 \times 156 \times$ $700 \mu \mathrm{m}^{3}$. e MR image of stem cells labelled with fluorescent nanoparticles containing Gd-DTPA, injected into the myocardium of a rat heart. Acquisition parameters for MRI: 3D T1W GRE sequence with $\mathrm{TE}=1.5 \mathrm{~ms}, \mathrm{TR}=11.1 \mathrm{~ms}, \alpha=50^{\circ}$ and resolution $215 \times 215 \times$ $600 \mu \mathrm{m}^{3}$ sequences [167], ultrashort echo times [168], off-resonance techniques [169] or other new developments in MR hardware or software may provide solutions in this respect. Whether these solutions will also help in distinguishing viable labelled cells from iron deposits released from dead or dying cells or macrophages that have engulfed dead cells is the question. A solution to the latter problem may be provided by MR reporter gene technology [84].

Most studies on cells labelled with contrast agents have demonstrated limited or no acute toxic effects on the labelled cells. It is, however, still unclear whether or not long-term toxic effects occur or whether or not the labelled cells might cause any toxic effects or show compromised function in vivo. In recent papers by Brekke et al. [40] and Modo et al. [170] the need for detailed, long-term, in vitro and in vivo assessment of the effects of contrast agent on cell function was clearly demonstrated. Using a Gd-based contrast agent (GRID), no detrimental effect of the contrast agent on neural stem cell viability, migratory capacity or multipotency was observed. Nonetheless, proliferative capacity of the cells was reduced, and the in vivo functional capacity of the cells was largely annihilated.

\section{Conclusions}

Although cell tracking with the MRI of paramagnetic labelled cells is very promising, there are still many challenges to overcome. The field is moving forwards quickly, and newly developed contrast agents and imaging technologies are very exciting. However, many hurdles will still be faced in translating these new particles and imaging strategies to the clinic. Issues regarding potential cellular and systemic toxicity need to be resolved. For 
instance, the recent discussion regarding the link between gadolinium-based contrast agents and nephrogenic systemic fibrosis (NSF) may hamper the licensing of newly developed Gd-based contrast agents. Imaging strategies developed on dedicated animal scanners may prove difficult to transfer to clinical scanners.

For further advancement of the field more systematic approaches and development of standardised (clinically applicable) protocols will be crucial. The focus should not only be on the ability to visualise cells with MRI, but also on methods of quantifying cells and for each (new) labelling approach detailed and thorough assessment of acute and chronic cell functionality should be performed. In order to facilitate comparison between different studies it would be very useful if the assessment of toxicity (on cell survival, cell proliferation or cell function) could be assessed using similar assays.

Acknowledgements The authors would like to acknowledge and thank Dr. Eric Farrell for supplying pictures on differentiated labeled stem cells. This paper has been written in part through support from ENCITE - funded by the European Community under the 7 th Framework program.

Open Access This article is distributed under the terms of the Creative Commons Attribution Noncommercial License which permits any noncommercial use, distribution, and reproduction in any medium, provided the original author(s) and source are credited.

\section{References}

1. Sutton EJ, Henning TD, Pichler BJ et al (2008) Cell tracking with optical imaging. Eur Radiol 18:2021-2032

2. Zhang Y, Ruel M, Beanlands RS et al (2008) Tracking stem cell therapy in the myocardium: applications of positron emission tomography. Curr Pharm Des 14:3835-3853

3. Kurpisz M, Czepczynski R, Grygielska B et al (2007) Bone marrow stem cell imaging after intracoronary administration. Int J Cardiol 121:194-195

4. Ye Y, Bogaert J (2008) Cell therapy in myocardial infarction: emphasis on the role of MRI. Eur Radiol 18:548-569

5. Crich SG, Biancone L, Cantaluppi V et al (2004) Improved route for the visualization of stem cells labeled with a Gd-/Eu-chelate as dual (MRI and fluorescence) agent. Magn Reson Med 51:938-944

6. Kraitchman DL, Heldman AW, Atalar $E$ et al (2003) In vivo magnetic resonance imaging of mesenchymal stem cells in myocardial infarction. Circulation 107:2290-2293

7. Arbab AS, Yocum GT, Kalish $\mathrm{H}$ et al (2004) Efficient magnetic cell labeling with protamine sulfate complexed to ferumoxides for cellular MRI. Blood 104:1217-1223

8. Modo M, Mellodew K, Cash D et al (2004) Mapping transplanted stem cell migration after a stroke: a serial, in vivo magnetic resonance imaging study. Neuroimage 21:311-317

9. Zhang Z, van den Bos EJ, Wielopolski PA et al (2005) In vitro imaging of single living human umbilical vein endothelial cells with a clinical 3.0-T MRI scanner. Magma 18:175-185
10. Hoehn M, Kustermann E, Blunk J et al (2002) Monitoring of implanted stem cell migration in vivo: a highly resolved in vivo magnetic resonance imaging investigation of experimental stroke in rat. Proc Natl Acad Sci USA 99:1626716272

11. Jendelova P, Herynek V, Urdzikova L et al (2004) Magnetic resonance tracking of transplanted bone marrow and embryonic stem cells labeled by iron oxide nanoparticles in rat brain and spinal cord. J Neurosci Res 76:232-243

12. Arbab AS, Yocum GT, Wilson LB et al (2004) Comparison of transfection agents in forming complexes with ferumoxides, cell labeling efficiency, and cellular viability. Mol Imaging 3:24-32

13. Bulte JW, Douglas T, Witwer B et al (2001) Magnetodendrimers allow endosomal magnetic labeling and in vivo tracking of stem cells. Nat Biotechnol 19:1141-1147

14. Daldrup-Link HE, Rudelius M, Oostendorp RA et al (2003) Targeting of hematopoietic progenitor cells with MR contrast agents. Radiology 228:760-767

15. de Vries IJ, Lesterhuis WJ, Barentsz JO et al (2005) Magnetic resonance tracking of dendritic cells in melanoma patients for monitoring of cellular therapy. Nat Biotechnol 23:1407-1413

16. Hinds KA, Hill JM, Shapiro EM et al (2003) Highly efficient endosomal labeling of progenitor and stem cells with large magnetic particles allows magnetic resonance imaging of single cells. Blood 102:867-872

17. Josephson L, Tung $\mathrm{CH}$, Moore A et al (1999) High-efficiency intracellular magnetic labeling with novel superparamagnetic-Tat peptide conjugates. Bioconjug Chem 10:186-191
18. Montet-Abou K, Montet X, Weissleder $R$ et al (2005) Transfection agent induced nanoparticle cell loading. Mol Imaging 4:165-171

19. Shapiro EM, Medford-Davis LN, Fahmy TM et al (2007) Antibodymediated cell labeling of peripheral $\mathrm{T}$ cells with micron-sized iron oxide particles (MPIOs) allows single cell detection by MRI. Contrast Media Mol Imaging 2:147-153

20. Slotkin JR, Cahill KS, Tharin SA et al (2007) Cellular magnetic resonance imaging: nanometer and micrometer size particles for noninvasive cell localization. Neurotherapeutics 4:428-433

21. Suzuki Y, Zhang S, Kundu P et al (2007) In vitro comparison of the biological effects of three transfection methods for magnetically labeling mouse embryonic stem cells with ferumoxides. Magn Reson Med 57:1173-1179

22. van den Bos EJ, Wagner A, Mahrholdt $\mathrm{H}$ et al (2003) Improved efficacy of stem cell labeling for magnetic resonance imaging studies by the use of cationic liposomes. Cell Transplant 12:743-756

23. Vuu K, Xie J, McDonald MA et al (2005) Gadolinium-rhodamine nanoparticles for cell labeling and tracking via magnetic resonance and optical imaging. Bioconjug Chem 16:995-999

24. Walczak P, Ruiz-Cabello J, Kedziorek DA et al (2006) Magnetoelectroporation: improved labeling of neural stem cells and leukocytes for cellular magnetic resonance imaging using a single FDA-approved agent. Nanomedicine 2:89-94 
25. Hoehn M, Himmelreich U, Kruttwig K et al (2008) Molecular and cellular MR imaging: potentials and challenges for neurological applications. J Magn Reson Imaging 27:941-954

26. Jing XH, Yang L, Duan XJ et al (2008) In vivo MR imaging tracking of magnetic iron oxide nanoparticle labeled, engineered, autologous bone marrow mesenchymal stem cells following intra-articular injection. Jt Bone Spine 75:432-438

27. Evgenov NV, Medarova Z, Dai G et al (2006) In vivo imaging of islet transplantation. Nat Med 12:144-148

28. Akins EJ, Dubey P (2008) Noninvasive imaging of cell-mediated therapy for treatment of cancer. J Nucl Med 49 (Suppl 2):180S-195S

29. Modo MJ, Bulte JWM (2007) Cellular and molecular MR imaging. CRC, Boca Raton

30. Budde MD, Frank JA (2009) Magnetic tagging of therapeutic cells for MRI. J Nucl Med 50:171-174

31. Gilad AA, Ziv K, McMahon MT et al (2008) MRI reporter genes. J Nucl Med 49:1905-1908

32. Himmelreich U, Hoehn M (2008) Stem cell labeling for magnetic resonance imaging. Minim Invasive Ther Allied Technol 17:132-142

33. Kraitchman DL, Bulte JW (2008) Imaging of stem cells using MRI. Basic Res Cardiol 103:105-113

34. Modo M (2008) Noninvasive imaging of transplanted cells. Curr Opin Organ Transplant 13:654-658

35. Sykova E, Jendelova P (2007) In vivo tracking of stem cells in brain and spinal cord injury. Prog Brain Res 161:367-383

36. Zhu J, Zhou L, XingWu F (2006) Tracking neural stem cells in patients with brain trauma. N Engl J Med 355:2376-2378

37. Toso C, Vallee JP, Morel P et al (2008) Clinical magnetic resonance imaging of pancreatic islet grafts after iron nanoparticle labeling. Am J Transplant 8:701-706

38. Aime S, Barge A, Cabella C et al (2004) Targeting cells with MR imaging probes based on paramagnetic Gd(III) chelates. Curr Pharm Biotechnol 5:509-518

39. Anderson SA, Lee KK, Frank JA (2006) Gadolinium-fullerenol as a paramagnetic contrast agent for cellular imaging. Invest Radiol 41:332-338

40. Brekke C, Morgan SC, Lowe AS et al (2007) The in vitro effects of a bimodal contrast agent on cellular functions and relaxometry. NMR Biomed 20:77-89
41. Choi JH, Nguyen FT, Barone PW et al (2007) Multimodal biomedical imaging with asymmetric single-walled carbon nanotube/iron oxide nanoparticle complexes. Nano Lett 7:861-867

42. Du L, Chen J, Qi Y et al (2007) Preparation and biomedical application of a non-polymer coated superparamagnetic nanoparticle. Int $\mathrm{J}$ Nanomedicine 2:805-812

43. Henning TD, Saborowski O, Golovko D et al (2007) Cell labeling with the positive MR contrast agent gadofluorine M. Eur Radiol 17:1226-1234

44. Hsiao JK, Tai MF, Chu HH et al (2007) Magnetic nanoparticle labeling of mesenchymal stem cells without transfection agent: cellular behavior and capability of detection with clinical 1.5 T magnetic resonance at the single cell level. Magn Reson Med 58:717724

45. Shen T, Weissleder R, Papisov $M$ et al (1993) Monocrystalline iron oxide nanocompounds (MION): physicochemical properties. Magn Reson Med 29:599-604

46. Strijkers GJ, Mulder WJ, van Tilborg GA et al (2007) MRI contrast agents: current status and future perspectives. Anticancer Agents Med Chem 7:291305

47. Tromsdorf UI, Bigall NC, Kaul MG et al (2007) Size and surface effects on the MRI relaxivity of manganese ferrite nanoparticle contrast agents. Nano Lett 7:2422-2427

48. Kim D, Hong KS, Song J (2007) The present status of cell tracking methods in animal models using magnetic resonance imaging technology. Mol Cells 23:132-137

49. Arbab AS, Yocum GT, Rad AM et al (2005) Labeling of cells with ferumoxides-protamine sulfate complexes does not inhibit function or differentiation capacity of hematopoietic or mesenchymal stem cells. NMR Biomed 18:553-559

50. Bulte JW, Kostura L, Mackay A et al (2005) Feridex-labeled mesenchymal stem cells: cellular differentiation and MR assessment in a canine myocardial infarction model. Acad Radiol 12 (Suppl 1):S2-S6

51. Kostura L, Kraitchman DL, Mackay AM et al (2004) Feridex labeling of mesenchymal stem cells inhibits chondrogenesis but not adipogenesis or osteogenesis. NMR Biomed 17:513517

52. Amsalem Y, Mardor Y, Feinberg MS et al (2007) Iron-oxide labeling and outcome of transplanted mesenchymal stem cells in the infarcted myocardium. Circulation 116:I38-I45
53. Farrell E, Wielopolski P, Pavljasevic P et al (2008) Effects of iron oxide incorporation for long term cell tracking on MSC differentiation in vitro and in vivo. Biochem Biophys Res Commun 369:1076-1081

54. Kustermann E, Himmelreich U, Kandal $\mathrm{K}$ et al (2008) Efficient stem cell labeling for MRI studies. Contrast Media Mol Imaging 3:27-37

55. Neri M, Maderna C, Cavazzin $C$ et al (2008) Efficient in vitro labeling of human neural precursor cells with superparamagnetic iron oxide particles: relevance for in vivo cell tracking. Stem Cells 26:505-516

56. Oude Engberink RD, van der Pol SM, Dopp EA et al (2007) Comparison of SPIO and USPIO for in vitro labeling of human monocytes: MR detection and cell function. Radiology 243:467474

57. Wang YX, Hussain SM, Krestin GP (2001) Superparamagnetic iron oxide contrast agents: physicochemical characteristics and applications in MR imaging. Eur Radiol 11:2319-2331

58. Heymer A, Haddad D, Weber $M$ et al (2008) Iron oxide labelling of human mesenchymal stem cells in collagen hydrogels for articular cartilage repair. Biomaterials 29:1473-1483

59. Stroh A, Zimmer C, Werner N et al (2006) Tracking of systemically administered mononuclear cells in the ischemic brain by high-field magnetic resonance imaging. Neuroimage 33:886-897

60. Taupitz M, Wagner S, Schnorr J et al (2004) Phase I clinical evaluation of citrate-coated monocrystalline very small superparamagnetic iron oxide particles as a new contrast medium for magnetic resonance imaging. Invest Radiol 39:394-405

61. Shen F, Li AA, Gong YK et al (2005) Encapsulation of recombinant cells with a novel magnetized alginate for magnetic resonance imaging. Hum Gene Ther 16:971-984

62. Munnier E, Cohen-Jonathan S, Linassier C et al (2008) Novel method of doxorubicin-SPION reversible association for magnetic drug targeting. Int J Pharm 363:170-176

63. Weissleder R, Cheng HC, Bogdanova A et al (1997) Magnetically labeled cells can be detected by MR imaging. J Magn Reson Imaging 7:258-263

64. Kircher MF, Allport JR, Graves EE et al (2003) In vivo high resolution threedimensional imaging of antigenspecific cytotoxic T-lymphocyte trafficking to tumors. Cancer Res 63:6838-6846 
65. Song M, Moon WK, Kim Y et al (2007) Labeling efficacy of superparamagnetic iron oxide nanoparticles to human neural stem cells: comparison of ferumoxides, monocrystalline iron oxide, cross-linked iron oxide (CLIO)$\mathrm{NH}_{2}$ and tat-CLIO. Korean J Radiol 8:365-371

66. Koch AM, Reynolds F, Kircher MF et al (2003) Uptake and metabolism of a dual fluorochrome Tat-nanoparticle in HeLa cells. Bioconjug Chem 14:11151121

67. Corot C, Robert P, Idee JM et al (2006) Recent advances in iron oxide nanocrystal technology for medical imaging. Adv Drug Deliv Rev 58:1471-1504

68. Jung CW (1995) Surface properties of superparamagnetic iron oxide MR contrast agents: ferumoxides, ferumoxtran, ferumoxsil. Magn Reson Imaging 13:675-691

69. Jung CW, Jacobs P (1995) Physical and chemical properties of superparamagnetic iron oxide MR contrast agents: ferumoxides, ferumoxtran, ferumoxsil. Magn Reson Imaging 13:661-674

70. Bulte JW, Kraitchman DL, Mackay AM et al (2004) Chondrogenic differentiation of mesenchymal stem cells is inhibited after magnetic labeling with ferumoxides. Blood 104:3410-3412; author reply 3412-3413

71. Siglienti I, Bendszus M, Kleinschnitz C et al (2006) Cytokine profile of ironladen macrophages: implications for cellular magnetic resonance imaging. J Neuroimmunol 173:166-173

72. Bulte JW, Hoekstra Y, Kamman RL et al (1992) Specific MR imaging of human lymphocytes by monoclonal antibody-guided dextran-magnetite particles. Magn Reson Med 25:148157

73. Lisy MR, Hartung A, Lang $\mathrm{C}$ et al (2007) Fluorescent bacterial magnetic nanoparticles as bimodal contrast agents. Invest Radiol 42:235-241

74. Veiseh O, Sun C, Gunn J et al (2005) Optical and MRI multifunctional nanoprobe for targeting gliomas. Nano Lett 5:1003-1008

75. Tai JH, Foster P, Rosales A et al (2006) Imaging islets labeled with magnetic nanoparticles at 1.5 Tesla. Diabetes 55:2931-2938

76. Groman EV, Bouchard JC, Reinhardt CP et al (2007) Ultrasmall mixed ferrite colloids as multidimensional magnetic resonance imaging, cell labeling, and cell sorting agents. Bioconjug Chem 18:1763-1771
77. Terrovitis JV, Bulte JW, Sarvananthan S et al (2006) Magnetic resonance imaging of ferumoxide-labeled mesenchymal stem cells seeded on collagen scaffolds-relevance to tissue engineering. Tissue Eng 12:2765-2775

78. Oliver M, Ahmad A, Kamaly N et al (2006) MAGfect: a novel liposome formulation for MRI labelling and visualization of cells. Org Biomol Chem 4:3489-3497

79. Kamaly N, Kalber T, Ahmad A et al (2008) Bimodal paramagnetic and fluorescent liposomes for cellular and tumor magnetic resonance imaging. Bioconjug Chem 19:118-129

80. Krishnan AS, Neves AA, de Backer MM et al (2008) Detection of cell death in tumors by using MR imaging and a gadolinium-based targeted contrast agent. Radiology 246:854-862

81. Cohen B, Ziv K, Plaks V et al (2007) MRI detection of transcriptional regulation of gene expression in transgenic mice. Nat Med 13:498-503

82. Kayyem JF, Kumar RM, Fraser SE et al (1995) Receptor-targeted co-transport of DNA and magnetic resonance contrast agents. Chem Biol 2:615-620

83. Zurkiya O, Chan AW, Hu X (2008) MagA is sufficient for producing magnetic nanoparticles in mammalian cells, making it an MRI reporter. Magn Reson Med 59:1225-1231

84. Gilad AA, Winnard PT Jr, van Zijl PC et al (2007) Developing MR reporter genes: promises and pitfalls. NMR Biomed 20:275-290

85. Weissleder R, Moore A, Mahmood U et al (2000) In vivo magnetic resonance imaging of transgene expression. Nat Med 6:351-355

86. Aoki I, Takahashi Y, Chuang KH et al (2006) Cell labeling for magnetic resonance imaging with the T1 agent manganese chloride. NMR Biomed 19:50-59

87. Sotak CH, Sharer K, Koretsky AP (2008) Manganese cell labeling of murine hepatocytes using manganese (III)-transferrin. Contrast Media Mol Imaging 3:95-105

88. Janjic JM, Srinivas M, Kadayakkara DK et al (2008) Self-delivering nanoemulsions for dual fluorine-19 MRI and fluorescence detection. J Am Chem Soc 130:2832-2841

89. Partlow KC, Chen J, Brant JA et al (2007) ${ }^{19} \mathrm{~F}$ magnetic resonance imaging for stem/progenitor cell tracking with multiple unique perfluorocarbon nanobeacons. FASEB J 21:1647-1654

90. Srinivas M, Morel PA, Ernst LA et al (2007) Fluorine-19 MRI for visualization and quantification of cell migration in a diabetes model. Magn Reson Med 58:725-734
91. Aime S, Carrera C, Delli Castelli D et al (2005) Tunable imaging of cells labeled with MRI-PARACEST agents. Angew Chem Int Ed Engl 44:18131815

92. Gilad AA, van Laarhoven HW, McMahon MT et al (2009) Feasibility of concurrent dual contrast enhancement using CEST contrast agents and superparamagnetic iron oxide particles. Magn Reson Med 61:970-974

93. Terreno E, Delli Castelli D, Cabella C et al (2008) Paramagnetic liposomes as innovative contrast agents for magnetic resonance (MR) molecular imaging applications. Chem Biodivers 5:19011912

94. Li AX, Wojciechowski F, Suchy M et al (2008) A sensitive PARACEST contrast agent for temperature MRI: $\mathrm{Eu}^{3+}$-DOTAM-glycine (Gly)phenylalanine (Phe). Magn Reson Med 59:374-381

95. Pikkemaat JA, Wegh RT, Lamerichs R et al (2007) Dendritic PARACEST contrast agents for magnetic resonance imaging. Contrast Media Mol Imaging 2:229-239

96. Yoo B, Raam MS, Rosenblum RM et al (2007) Enzyme-responsive PARACEST MRI contrast agents: a new biomedical imaging approach for studies of the proteasome. Contrast Media Mol Imaging 2:189-198

97. Golman K, Petersson JS (2006) Metabolic imaging and other applications of hyperpolarized $13 \mathrm{C} 1$. Acad Radiol 13:932-942

98. Zhao JM, Har-El YE, McMahon MT et al (2008) Size-induced enhancement of chemical exchange saturation transfer (CEST) contrast in liposomes. J Am Chem Soc 130:5178-5184

99. Terreno E, Delli Castelli D, Violante E et al (2009) Osmotically shrunken LIPOCEST agents: an innovative class of magnetic resonance imaging contrast media based on chemical exchange saturation transfer. Chemistry 15:14401448

100. Day SE, Kettunen MI, Gallagher FA et al (2007) Detecting tumor response to treatment using hyperpolarized ${ }^{13} \mathrm{C}$ magnetic resonance imaging and spectroscopy. Nat Med 13:1382-1387

101. Macdonald JM, Schmidlin O, James TL (2002) In vivo monitoring of hepatic glutathione in anesthetized rats by ${ }^{13} \mathrm{C}$ NMR. Magn Reson Med 48:430-439

102. Johansson E, Olsson LE, Mansson S et al (2004) Perfusion assessment with bolus differentiation: a technique applicable to hyperpolarized tracers. Magn Reson Med 52:1043-1051 
103. Gallagher FA, Kettunen MI, Day SE et al (2008) Magnetic resonance imaging of $\mathrm{pH}$ in vivo using hyperpolarized ${ }^{13} \mathrm{C}$-labelled bicarbonate. Nature 453:940-943

104. Conner SD, Schmid SL (2003) Regulated portals of entry into the cell. Nature 422:37-44

105. Polo S, Di Fiore PP (2006) Endocytosis conducts the cell signaling orchestra. Cell 124:897-900

106. Samaj J, Baluska F, Voigt B et al (2004) Endocytosis, actin cytoskeleton, and signaling. Plant Physiol 135:1150-1161

107. Arbab AS, Liu W, Frank JA (2006) Cellular magnetic resonance imaging: current status and future prospects. Expert Rev Med Devices 3:427-439

108. Daldrup-Link HE, Rudelius M, Oostendorp RA et al (2005) Comparison of iron oxide labeling properties of hematopoietic progenitor cells from umbilical cord blood and from peripheral blood for subsequent in vivo tracking in a xenotransplant mouse model XXX. Acad Radiol 12:502-510

109. Thorek DL, Tsourkas A (2008) Size, charge and concentration dependent uptake of iron oxide particles by nonphagocytic cells. Biomaterials 29:3583-3590

110. Byk T, Haddada H, Vainchenker W et al (1998) Lipofectamine and related cationic lipids strongly improve adenoviral infection efficiency of primitive human hematopoietic cells. Hum Gene Ther 9:2493-2502

111. Liu C, Dalby B, Chen W et al (2008) Transient transfection factors for highlevel recombinant protein production in suspension cultured mammalian cells. Mol Biotechnol 39:141-153

112. Walsh M, Tangney M, O’Neill MJ et al (2006) Evaluation of cellular uptake and gene transfer efficiency of pegylated poly-L-lysine compacted DNA: implications for cancer gene therapy. Mol Pharm 3:644-653

113. Kim TW, Chung H, Kwon IC et al (2005) Polycations enhance emulsionmediated in vitro and in vivo transfection. Int J Pharm 295:35-45

114. Lewin M, Carlesso N, Tung CH et al (2000) Tat peptide-derivatized magnetic nanoparticles allow in vivo tracking and recovery of progenitor cells. Nat Biotechnol 18:410-414

115. Walczak P, Kedziorek DA, Gilad AA et al (2005) Instant MR labeling of stem cells using magnetoelectroporation. Magn Reson Med 54:769-774
116. Terreno E, Geninatti Crich S, Belfiore $S$ et al (2006) Effect of the intracellular localization of a Gd-based imaging probe on the relaxation enhancement of water protons. Magn Reson Med 55:491-497

117. Odani N, Ito K, Nakamura H (2008) Electroporation as an efficient method of gene transfer. Dev Growth Differ 50 (6): $443-448$

118. Siemen H, Nix M, Endl E et al (2005) Nucleofection of human embryonic stem cells. Stem Cells Dev 14:378-383

119. Jiang Q, Zhang ZG, Ding GL et al (2005) Investigation of neural progenitor cell induced angiogenesis after embolic stroke in rat using MRI. Neuroimage 28:698-707

120. Zhang ZG, Jiang Q, Zhang $R$ et al (2003) Magnetic resonance imaging and neurosphere therapy of stroke in rat. Ann Neurol 53:259-263

121. Wang S, Zhang C, Zhang L et al (2008) The relative immunogenicity of DNA vaccines delivered by the intramuscular needle injection, electroporation and gene gun methods. Vaccine 26:2100-2110

122. Kang HW, Josephson L, Petrovsky A et al (2002) Magnetic resonance imaging of inducible E-selectin expression in human endothelial cell culture. Bioconjug Chem 13:122-127

123. Paschkunova-Martic I, Kremser C, Mistlberger K et al (2005) Design, synthesis, physical and chemical characterisation, and biological interactions of lectin-targeted latex nanoparticles bearing Gd-DTPA chelates: an exploration of magnetic resonance molecular imaging (MRMI). Histochem Cell Biol 123:283-301

124. Schafer R, Wiskirchen J, Guo K et al (2007) Aptamer-based isolation and subsequent imaging of mesenchymal stem cells in ischemic myocard by magnetic resonance imaging. Rofo 179:1009-1015

125. Kim HC, Han BH, Lee CH et al (2007) Registration of sheep brain MR images for cell tracking using ferritecomposite micro-beads as markers. Conf Proc IEEE Eng Med Biol Soc 2007:6384-6387

126. Anderson SA, Glod J, Arbab AS et al (2005) Noninvasive MR imaging of magnetically labeled stem cells to directly identify neovasculature in a glioma model. Blood 105:420-425

127. Pirko I, Johnson A, Ciric B et al (2004) In vivo magnetic resonance imaging of immune cells in the central nervous system with superparamagnetic antibodies. FASEB J 18:179-182

128. Rogers WJ, Meyer CH, Kramer CM (2006) Technology insight: in vivo cell tracking by use of MRI. Nat Clin Pract Cardiovasc Med 3:554-562
129. Ahrens ET, Flores $\mathrm{R}, \mathrm{Xu} \mathrm{H}$ et al (2005) In vivo imaging platform for tracking immunotherapeutic cells. Nat Biotechnol 23:983-987

130. Zong Y, Guo J, Ke T et al (2006) Effect of size and charge on pharmacokinetics and in vivo MRI contrast enhancement of biodegradable polydisulfide Gd(III) complexes. J Control Release 112:350-356

131. Bulte JW (2006) Intracellular endosomal magnetic labeling of cells. Methods Mol Med 124:419-439

132. Jendelova P, Herynek V, DeCroos J et al (2003) Imaging the fate of implanted bone marrow stromal cells labeled with superparamagnetic nanoparticles. Magn Reson Med 50:767776

133. Moore A, Sun PZ, Cory D et al (2002) MRI of insulitis in autoimmune diabetes. Magn Reson Med 47:751758

134. Parmley RT, Spicer SS, Alvarez CJ (1978) Ultrastructural localization of nonheme celluar iron with ferrocyanide. J Histochem Cytochem 26:729-741

135. Arab K, Steghens JP (2004) Plasma lipid hydroperoxides measurement by an automated xylenol orange method. Anal Biochem 325:158-163

136. Beer AJ, Holzapfel K, Neudorfer J et al (2008) Visualization of antigenspecific human cytotoxic T lymphocytes labeled with superparamagnetic iron-oxide particles. Eur Radiol 18:1087-1095

137. Ahrens ET, Feili-Hariri M, Xu H et al (2003) Receptor-mediated endocytosis of iron-oxide particles provides efficient labeling of dendritic cells for in vivo MR imaging. Magn Reson Med 49:1006-1013

138. Berd D (2003) Contribution of dead cells to the immunogenicity of an autologous, hapten-modified melanoma vaccine. Vaccine 21:795-797

139. Berridge MV, Herst PM, Tan AS (2005) Tetrazolium dyes as tools in cell biology: new insights into their cellular reduction. Biotechnol Annu Rev 11:127-152

140. Perfetto SP, Chattopadhyay PK, Lamoreaux L et al (2006) Amine reactive dyes: an effective tool to discriminate live and dead cells in polychromatic flow cytometry. J Immunol Methods 313:199-208

141. Herzog E, Casey A, Lyng FM et al (2007) A new approach to the toxicity testing of carbon-based nanomaterialsthe clonogenic assay. Toxicol Lett 174:49-60 
142. Nakayama GR, Caton MC, Nova MP et al (1997) Assessment of the Alamar Blue assay for cellular growth and viability in vitro. J Immunol Methods 204:205-208

143. Merrill GF (1998) Cell synchronization. Methods Cell Biol 57:229-249

144. Yan L, Han Y, He Y et al (2007) Cell tracing techniques in stem cell transplantation. Stem Cell Rev 3:265-269

145. Callard R, Hodgkin P (2007) Modeling $\mathrm{T}$ - and $\mathrm{B}$-cell growth and differentiation. Immunol Rev 216:119-129

146. Wilhelm C, Bal L, Smirnov P et al (2007) Magnetic control of vascular network formation with magnetically labeled endothelial progenitor cells. Biomaterials 28:3797-3806

147. Yamamoto K, Takahashi T, Asahara T et al (2003) Proliferation, differentiation, and tube formation by endothelial progenitor cells in response to shear stress. J Appl Physiol 95:2081-2088

148. Kleinman HK, Jacob K (2001) Invasion assays. Curr Protoc Cell Biol Chap 12:Unit 12.2

149. Magnitsky S, Walton RM, Wolfe JH et al (2007) Magnetic resonance imaging as a tool for monitoring stem cell migration. Neurodegener Dis 4:314321

150. Raymond KN, Pierre VC (2005) Next generation, high relaxivity gadolinium MRI agents. Bioconjug Chem 16:3-8

151. Biancone L, Crich SG, Cantaluppi V et al (2007) Magnetic resonance imaging of gadolinium-labeled pancreatic islets for experimental transplantation. NMR Biomed 20:40-48

152. Bos C, Delmas Y, Desmouliere A et al (2004) In vivo MR imaging of intravascularly injected magnetically labeled mesenchymal stem cells in rat kidney and liver. Radiology 233:781789

153. Bulte JW, Zhang S, van Gelderen P et al (1999) Neurotransplantation of magnetically labeled oligodendrocyte progenitors: magnetic resonance tracking of cell migration and myelination. Proc Natl Acad Sci USA 96:15256-15261

154. Ittrich $\mathrm{H}$, Lange $\mathrm{C}$, Togel $\mathrm{F}$ et al (2007) In vivo magnetic resonance imaging of iron oxide-labeled, arterially-injected mesenchymal stem cells in kidneys of rats with acute ischemic kidney injury: detection and monitoring at $3 \mathrm{~T}$. J Magn Reson Imaging 25:1179-1191
155. Daldrup-Link HE, Rudelius M, Metz S et al (2004) Cell tracking with gadophrin-2: a bifunctional contrast agent for MR imaging, optical imaging, and fluorescence microscopy. Eur J Nucl Med Mol Imaging 31:1312-1321

156. Foster-Gareau P, Heyn C, Alejski A et al (2003) Imaging single mammalian cells with a $1.5 \mathrm{~T}$ clinical MRI scanner. Magn Reson Med 49:968971

157. Hill JM, Dick AJ, Raman VK et al (2003) Serial cardiac magnetic resonance imaging of injected mesenchymal stem cells. Circulation 108:10091014

158. Politi LS (2007) MR-based imaging of neural stem cells. Neuroradiology 49:523-534

159. Rad AM, Arbab AS, Iskander AS et al (2007) Quantification of superparamagnetic iron oxide (SPIO)-labeled cells using MRI. J Magn Reson Imaging 26:366-374

160. Cunningham $\mathrm{CH}$, Arai T, Yang $\mathrm{PC}$ et al (2005) Positive contrast magnetic resonance imaging of cells labeled with magnetic nanoparticles. Magn Reson Med 53:999-1005

161. Mani V, Adler E, Briley-Saebo KC et al (2008) Serial in vivo positive contrast MRI of iron oxide-labeled embryonic stem cell-derived cardiac precursor cells in a mouse model of myocardial infarction. Magn Reson Med 60:73-81

162. Mani V, Briley-Saebo KC, Itskovich VV et al (2006) Gradient echo acquisition for superparamagnetic particles with positive contrast (GRASP): sequence characterization in membrane and glass superparamagnetic iron oxide phantoms at $1.5 \mathrm{~T}$ and $3 \mathrm{~T}$. Magn Reson Med 55:126-135

163. Suzuki Y, Cunningham CH, Noguchi $\mathrm{K}$ et al (2008) In vivo serial evaluation of superparamagnetic iron-oxide labeled stem cells by off-resonance positive contrast. Magn Reson Med 60:1269-1275

164. Bowen CV, Zhang X, Saab G et al (2002) Application of the static dephasing regime theory to superparamagnetic iron-oxide loaded cells. Magn Reson Med 48:52-61

165. Dahnke H, Schaeffter T (2005) Limits of detection of SPIO at 3.0 T using T2 relaxometry. Magn Reson Med 53:1202-1206

166. Pintaske J, Muller-Bierl B, Schick F (2006) Effect of spatial distribution of magnetic dipoles on Lamor frequency distribution and MR signal decay - a numerical approach under static dephasing conditions. MAGMA 19:46-53
167. Ro YM, Cho ZH (1995) Susceptibility magnetic resonance imaging using spectral decomposition. Magn Reson Med 33:521-528

168. Blamire AM (2008) The technology of MRI-the next 10 years? Br J Radiol 81:601-617

169. Farrar CT, Dai G, Novikov M et al (2008) Impact of field strength and iron oxide nanoparticle concentration on the linearity and diagnostic accuracy of off-resonance imaging. NMR Biomed 21:453-463

170. Modo M, Beech JS, Meade TJ et al (2008) A chronic 1 year assessment of MRI contrast agent-labelled neural stem cell transplants in stroke. Neuroimage. doi:10.1016/j. neuroimage.2008.06.017

171. Thompson RB, Parsa CJ, van den Bos EJ et al (2004) Video-assisted thoracoscopic transplantation of myoblasts into the heart. Ann Thorac Surg 78:303-307

172. Arbab AS, Bashaw LA, Miller BR et al (2003) Intracytoplasmic tagging of cells with ferumoxides and transfection agent for cellular magnetic resonance imaging after cell transplantation: methods and techniques. Transplantation 76:1123-1130

173. Ju S, Teng GJ, Lu H et al (2007) In vivo MR tracking of mesenchymal stem cells in rat liver after intrasplenic transplantation. Radiology 245:206215

174. Bogdanov A Jr, Matuszewski L, Bremer C et al (2002) Oligomerization of paramagnetic substrates result in signal amplification and can be used for MR imaging of molecular targets. Mol Imaging 1:16-23

175. Lee IH, Bulte JW, Schweinhardt P et al (2004) In vivo magnetic resonance tracking of olfactory ensheathing glia grafted into the rat spinal cord. Exp Neurol 187:509-516

176. Jiang Q, Zhang ZG, Ding GL et al (2006) MRI detects white matter reorganization after neural progenitor cell treatment of stroke. Neuroimage 32:1080-1089

177. Bhorade R, Weissleder R, Nakakoshi $\mathrm{T}$ et al (2000) Macrocyclic chelators with paramagnetic cations are internalized into mammalian cells via a HIV-tat derived membrane translocation peptide. Bioconjug Chem 11:301305 
178. Garden OA, Reynolds PR, Yates J et al (2006) A rapid method for labelling CD4+ T cells with ultrasmall paramagnetic iron oxide nanoparticles for magnetic resonance imaging that preserves proliferative, regulatory and migratory behaviour in vitro. J Immunol Methods 314:123-133

179. Zhao M, Kircher MF, Josephson L et al (2002) Differential conjugation of tat peptide to superparamagnetic nanoparticles and its effect on cellular uptake. Bioconjug Chem 13:840-844

180. Crich SG, Lanzardo S, Barge A et al (2005) Visualization through magnetic resonance imaging of DNA internalized following "in vivo" electroporation. Mol Imaging 4:7-17
181. Guignet EG, Meyer T (2008) Suspended-drop electroporation for high-throughput delivery of biomolecules into cells. Nat Methods 5:393-395

182. Zhang Z, Jiang Q, Jiang F et al (2004) In vivo magnetic resonance imaging tracks adult neural progenitor cell targeting of brain tumor. Neuroimage 23:281-287

183. Polyak B, Fishbein I, Chorny M et al (2008) High field gradient targeting of magnetic nanoparticle-loaded endothelial cells to the surfaces of steel stents. Proc Natl Acad Sci USA 105:698-703

184. Berry CC, Charles S, Wells S et al (2004) The influence of transferrin stabilised magnetic nanoparticles on human dermal fibroblasts in culture. Int J Pharm 269:211-225
185. Dodd $\mathrm{CH}, \mathrm{Hsu} \mathrm{HC}$, Chu WJ et al (2001) Normal T-cell response and in vivo magnetic resonance imaging of $T$ cells loaded with HIV transactivatorpeptide-derived superparamagnetic nanoparticles. J Immunol Methods 256:89-105

186. Stroh A, Faber C, Neuberger T et al (2005) In vivo detection limits of magnetically labeled embryonic stem cells in the rat brain using high-field $(17.6 \mathrm{~T})$ magnetic resonance imaging. Neuroimage 24:635-645 